\begin{tabular}{|l|c|c|c|c|}
\hline $\begin{array}{l}\text { Cuadernos de Investigación Geográfica } \\
\text { Geographical Research Letters }\end{array}$ & 2019 & N $^{\circ} 45(2)$ & pp. 623-660 & eISSN 1697-9540 \\
\hline
\end{tabular}

\title{
OUTSTANDING ATLANTIC NATURE AND CULTURE FOR UNESCO WORLD HERITAGE LIST: TRANSHUMANCE/ TRASTERMINANCE LANDSCAPE OF SOMIEDO AND ROYAL WAY OF LA MESA (ASTURIAN MASSIF, NW OF SPAIN)
}

\author{
C. RODRÍGUEZ*, J. SEVILLA, Í. OBESO \\ Department of Geography, University of Oviedo, \\ C/ Amparo Pedregal s/n, 33011 Oviedo, Spain.
}

\begin{abstract}
A change in the attitude of society towards nature and landscape (first established in the intellectual sphere and later adopted by institutions and other agents) operates in the evolution of the notion of heritage so that a territorial dimension of this concept emerges. Its consolidation is slow, both in the generalization of actions and in the conceptualization: it finds pioneering manifestations in the second half of the $19^{\text {th }}$ century and is considered to be widespread since UNESCO's Convention Concerning the Protection of the World Heritage, held in Paris in 1972. The later addition of the cultural landscape figure in the actions by this organization (1992) and the possibility of including mountain areas as World Heritage in a mixed natural-cultural type have stimulated the elaboration of this study. The purpose is to provide keys for the characterization and qualification of a mountain area already considered as a possible candidate in the UNESCO tentative list (Somiedo, $N W$ of Spain) in order to highlight its potential as Word Heritage. Research in this sector is also presented as a test for the development of a model that could serve as a complement for candidacies in other mountain regions with profiles or categories related to the one analyzed here: transhumance and/or trasterminance landscape in Atlantic mountains. The adequacy of Somiedo, particularly Saliencia Valley and Royal Way of La Mesa (somedan strecht) as a linked centennial itinerary, is justified by the diversity of UNESCO criteria that can be met, reflecting the diversity of outstanding features associated with natural and cultural elements and phenomena. The result could be the starting point for a further task: the formulation of concrete measures for the preservation of fundamental material and immaterial elements and the conception of an integral management program.
\end{abstract}


Naturaleza y cultura atlántica excepcional para la Lista del Patrimonio Mundial de la UNESCO: paisaje de trashumancia/trasterminancia de Somiedo y Camín Real de La Mesa (Macizo Asturiano, NO de España)

RESUMEN. En la evolución de la noción de patrimonio opera un cambio de actitud de la sociedad hacia la naturaleza y el paisaje (primero fraguada en el ámbito intelectual y después adoptada por instituciones y otros agentes) que hace emerger una nueva dimensión territorial de este concepto. Su consolidación es lenta, tanto en la generalización de las acciones como en la conceptualización: encuentra manifestaciones pioneras al avanzar la segunda mitad del siglo XIX y se considera completamente extendida a partir de la Convención para la Protección del Patrimonio Mundial celebrada en París en 1972. La posterior incorporación de la figura de paisaje cultural en las actuaciones de esta organización (1992) y la posibilidad de incluir áreas de montaña como espacios Patrimonio Mundial de tipo mixto natural-cultural han estimulado la elaboración de este estudio. El propósito es aportar las claves para la caracterización y cualificación de un área de montaña considerada como posible candidata en la lista indicativa de la UNESCO (Somiedo, noroeste de España) con el fin de subrayar su potencial como Patrimonio Mundial. La investigación en este sector de montaña se presenta a modo de ensayo para el desarrollo de un modelo que podría servir de complemento para candidaturas en otros espacios de montaña con perfiles o categorías relacionadas con la aquí analizada: paisajes ganaderos de trashumancia y trasterminancia en montañas atlánticas. La adecuación de Somiedo, particularmente del valle de Saliencia y del tramo somedano del Camín Real de La Mesa como itinerario centenario vinculado, se justifica por la diversidad de criterios UNESCO susceptibles de cumplimiento, reflejo de la diversidad de rasgos excepcionales asociados a los elementos y fenómenos naturales y culturales. El resultado podría suponer el punto de partida para una tarea ulterior: la formulación de medidas concretas para la preservación de los elementos materiales e inmateriales fundamentales y la concepción de un programa de gestión integral.

Key words: UNESCO, World Heritage, Somiedo, Royal Way of La Mesa, Asturian Massif, northwest of Spain.

Palabras clave: UNESCO, Patrimonio Mundial, Somiedo, Camín Real de La Mesa, Macizo Asturiano, Noroeste de España.

Received: 16 October 2018

Accepted: 6 December 2018

*Corresponding author: Carmen Rodríguez, Department of Geography, University of Oviedo, C/ Amparo Pedregal s/n, 33011 Oviedo, Spain. E-mail address: crperez@uniovi.es

\section{Introduction}

During the last two centuries the notion of 'heritage' overcame its original link to approaches supported by aesthetic considerations and related to the historical and symbolic 
transcendence of monumental artistic works. Heritage has come to include all kinds of material and immaterial realities with relevant values for the community. Indeed, in recent decades, heritage approaches are linked to concerns that have to do with the willingness of a community to protect and transmit all valuable manifestation of its memory and culture, as well as the areas in which they are rooted (Béghain, 1998; Poulot, 1998; Bouisset and Degrémont, 2010).

This evolution has also involved a renewed vision of society towards nature and landscape so that a territorial and landscape dimension of heritage has emerged concerning geographical zones characterized by their representativeness, singularity, rarity, state of conservation, symbolism, etc. (Ashby, 1978; Berdoulay, 1992; Martínez de Pisón, 1997; Béghain, 1998). Moreover, heritage is integrated into scientific and institutional reflections on the preservation of nature and the importance of landscape as a public good (for sensory enjoyment but also as a source of sociocultural learning and sustainable development, reflecting collective practices and territorial identities) (Guillaume, 1990; Nogué, 2010).

In this context, certain areas or itineraries acquire the quality of heritage through actions of recognition, study or enjoyment due to social, scientific and institutional actors. From exploration campaigns, excursions or trips, in fieldwork or recreational practices, these actors identify ecological, aesthetic, historical, ethnographic values, etc. And they promote their knowledge convinced that, due to their interest or social relevance, they must be contemplated, valued, shared and protected (Clark and Drury, 2002; Besse, 2009; Bouisset et al., 2010; Fernández and Silva, 2015; Rodríguez and Sevilla, 2017).

This type of process has been noticeable since the nineteenth century in mountain regions whose exceptional character is attributed when certain intellectual factors converge: the deepening of knowledge; the ideal of exploring sectors that are not easily accessible; the conception of mountain as a source of physical and moral regeneration, apart from considerations about beauty based on aesthetic concepts very evoked in that period (Martínez de Pisón, 2004; Maderuelo, 2007; Ortega, 2010; Gómez, 2013). This set of interests also stimulates the conception of the first official state actions to protect nature since the last third of the 19th century. The valuation of mountain as heritage participates in those actions in a more explicit or implicit way depending on the weight that cultural, aesthetic and ethical considerations have in each region and the terminology used in each case.

This territorial dimension of heritage consolidates during the 20th century and is considered as widespread since UNESCO's Convention Concerning the Protection of the World Cultural and Natural Heritage, held in Paris in 1972 (Serrano, 2012; Gómez, 2013). Also at this time, partly by the determinations of this international organization, the use of the term 'heritage' applied to the object of geographical science becomes generalized. More recently, the addition of cultural landscape figure in operational guidelines of the World Heritage Convention, registered in 1992, has been relevant (Droste et al., 1995; Aplin, 2007; Luengo and Rössler, 2012; Rodrigo et al., 2012); as well as the Council of Europe Landscape Convention (signed in Florence in 2000) conceiving landscape as a fundamental component of the European natural and cultural heritage, contributing to the well-being of humanity (Council of Europe, 2018). 
One of the interesting aspects of UNESCO's work, which inspires the approach of this article, has to do with the addition of cultural landscape figure in the World Heritage List operations and with the possibility that certain mountain areas receive a designation as mixed natural-cultural type, emphasizing the visual dimension of territory (Fernández and Silva, 2015; Mata, 2015; UNESCO, 2018a). The purpose is to provide analysis and keys for the characterization and qualification of a mountain area included in the UNESCO tentative list (Somiedo, NW of Spain) in order to advance the justification of its oustanding value and to highlight its potential as World Heritage (Porcal, 2014; Fernández and Silva, 2015; Mata, 2015; UNESCO, 2018b). We particularly refer to transhumance and/or trasterminance landscape in Atlantic mountains: transhumance/trasterminance landscape of Somiedo.

\section{Study area}

Given that a World Heritage designation carries out an evaluation of attributes that are not always easily measurable, it is necessary to define a rational method both to properly justify new candidacies and to organize the wills of the different administrations and agents involved. One of the first questions to be resolved is the choice of an appropriate scale. Taking into account the scalar variability in the natural and agro-rural component of landscapes, this study assumes that scales of heritage landscapes, also in agreement with the considerations of UNESCO, are the intermediate ones (Mata et al., 2012; Mata, 2015). On the other hand, there is the delimitation of the study area. The choice of Somiedo has been motivated by its inclusion in the tentative list of UNESCO (mixed natural-cultural type), next to the Ancares region (in León, Castile and León, and Lugo, Galicia), and the existence of a previous unconsolidated case file (from 2007) to be now reinvigorated. However, both mountain spaces being included within the western Cantabrian mountain range and containing some common natural and ethnographic features, it seemed pertinent to separate their study given their location in not exactly the same bioclimatic domains (this criterion is also supported in the Spanish landscape classification by Sanz and Mata, 2003). And the conjunction of territorial attributes is not the same in the whole Ancares-Somiedo area promoted in 2007. In short, the precise limit would be the same as the municipality of Somiedo, which is already used by the regional government of Asturias and UNESCO in the delimitation of Somiedo Natural Park and its corresponding Biosphere Reserve. It is located in the central-western sector of the Cantabrian mountain range, next to the Asturian administrative limit and occupying approximately 29,100 hectares. We have specially focused on Saliencia Valley and La Mesa mountain sector as they concentrate the most representative sample of Somiedo attributes.

The lithological alternation (quartzites, mountain limestones and slates), the folded arrangement of the materials as a result of the intense tectonic thrusts occurred more than 280 million years ago (Hercynian orogeny), and the reactivation of differential erosion after the Alpine tectonic movements, have led to the formation of a very rugged relief in this area, in which the Appalachian structural model is recognized. Together with this characteristic, the presence of clear glacial reliefs in the highest areas, and the importance acquired by the periglacial manifestations throughout the territory, confer a great landscape diversity that makes Somiedo especially attractive. In addition, the 
conservation of wide natural arboreal areas, mainly beech forests, and the presence of species in danger of extinction (brown bear and capercaillie) characterize Somiedo.

Along with physical features, a key element to understand the configuration of Somiedo's landscape is the importance of livestock activities. Here we find a representative example of Atlantic transhumance/trasterminance and some associated constructions (brañas with cabanas de teito). They form the scenario of a way of life that has been developed over centuries and has managed to adapt to the limitations imposed by the environment, helping to model an integrated landscape in which its originality can still be recognized thanks to the maintenance of a quality beef cattle (preserving its traditional know-how). Added to the above, the link of this territory to a very unique culture, that of the vaqueiros de alzada, contributes to enrich the cultural heritage and, therefore, to increase its interest.

\section{Methods}

Conducting the study requires determining the profile or category of the selected area within landscape typologies in order to identify the achievable UNESCO criteria (compliance with just one of the ten is sufficient) and the indicators that could reflect the Outstanding Universal Value, integrity and authenticity. The categorizations by UNESCO (2018a, 2018b) and Spanish National Plan of Cultural Landscapes have been used, with the nuances proposed by Sanz and Mata (2003) and Molinero et al. (2011, 2013). According to the bases of our project, supported by these authors, the category would be: "Transhumance and/or trasterminance landscape in Atlantic mountains. Transhumance and trasterminance landscape of Somiedo". According to UNESCO typology, it is a mixed natural-cultural and evolutionary living landscape that preserves an active social function in contemporary society closely linked to the traditional way of life. However, due to the loss of some traditional practices that generated singular landscape features, which are still visible, it can be considered as a relic landscape in some sectors. On the other hand, according to the classification proposal for cultural landscapes by Fernández and Silva (2015), supported by Rodrigo et al. (2012), Somiedo can be considered as: 0. Landscapes related to identity and the feeling of territorial belonging. 0.0 Identity; 1. Settlement systems. 1.1. Rural dominant; 4. Production systems. 4.1. Agrarian and fishing.

The definition of indicators to accord with the most achievable UNESCO criteria (Tables 1 and 2) has been based on a review of several dozen scientific publications and documentary sources (territorial structures, heritage recognition and nature protection, tourism...). Features considered in the recognition of other mixed natural-cultural mountain properties included in World Heritage List have also been used as a reference: the only two on the European Atlantic facade (Laponian Area, in Sweden; St. Kilda archipelago, in United Kingdom) and the southernmost in Western Europe (transboundary Pyrenees-Mont Perdu, in France-Spain). It must be taken into account that UNESCO criteria are applied in candidatures without the reference of a global study for the set of lanscape categories that contribute to rationalize the proposals. For this reason, it is convenient to prove in a sufficiently objective way that a certain area deserves to enter the List. The current UNESCO demand for comparative studies is a step forward, contrasting the value of a candidacy with that of territories that are already World Heritage, to confirm its relevance as well as its uniqueness. 
Table 1. Suitable UNESCO criteria for Somiedo's candidacy.

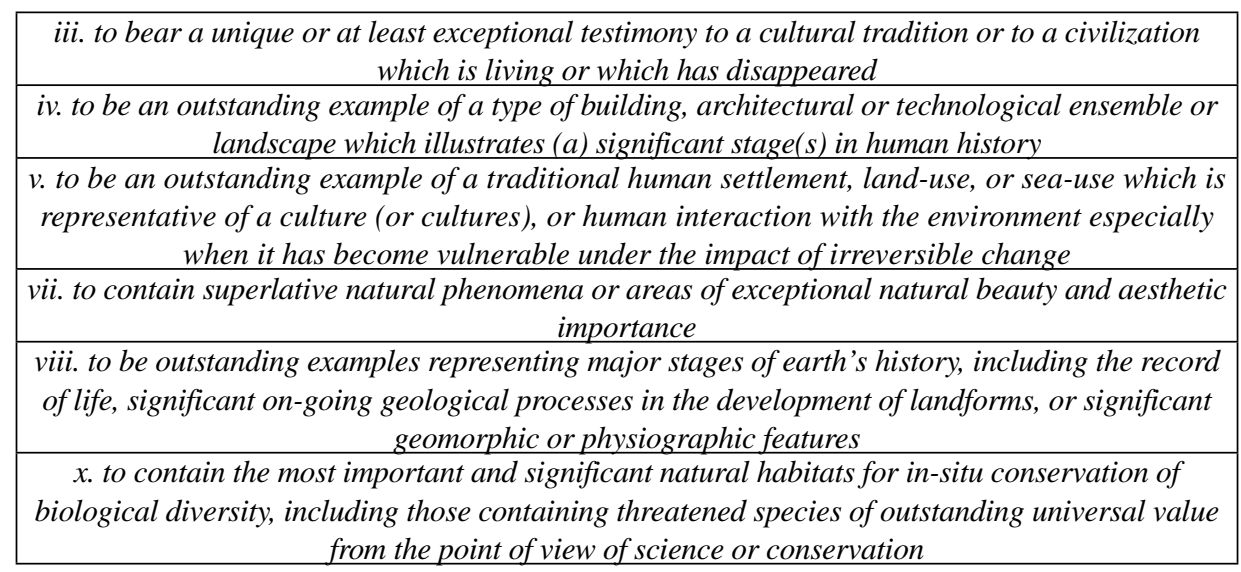

Source: UNESCO (2018a, 2018b).

Table 2. Indicators to assess compliance with UNESCO criteria.

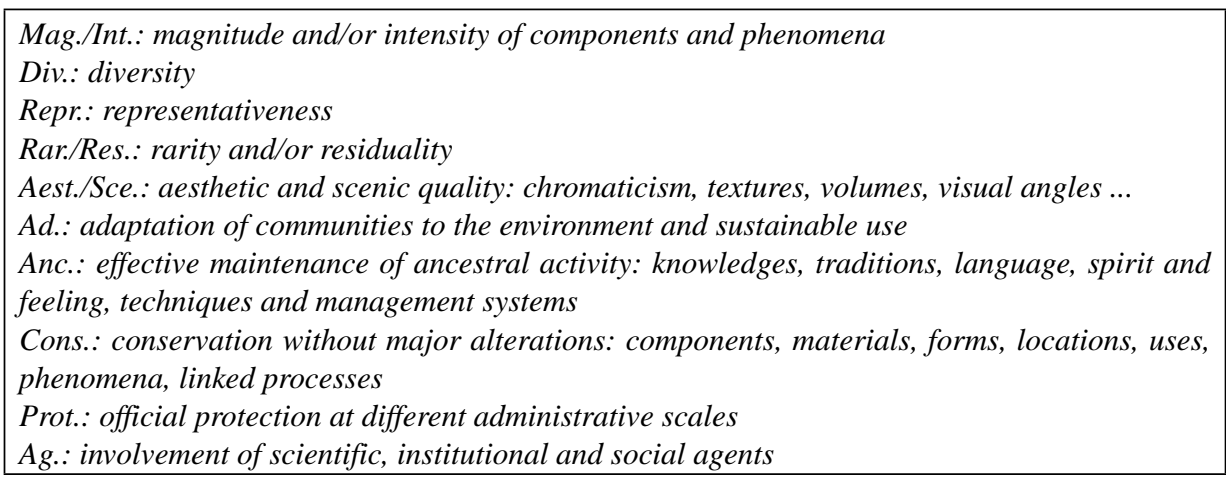

Source: Own elaboration supported by Bouisset et al. (2010), Rodríguez and Sevilla (2017) and UNESCO (2018a, 2018b).

Subsequently, the territorial and landscape keys have been characterized in order to attest and underline the presence of indicators that validate compliance with UNESCO criteria and point to the presence of Outstanding Universal Value, integrity and authenticity. To identify, classify and order all the information that would allow the determination of territorial and landscape keys, an in-depth review of publications has been essential, and their contributions have been completed with our fieldwork. We have had to proceed like this, from a systematic review of previous studies, in order to cover all the specificity and uniqueness of Somiedo and its very representative Saliencia Valley. Specifically, in this phase of the research a total of fifty publications have been consulted on topics as diverse as geology, ecology, botany, linguistics, ethnography, architecture, archeology, geography, history, anthropology, sociology, economics, among other fields, which reinforces the potential and rigor of the present study. 
In the fieldwork phase, study has been structured around an itinerary with a historicalgeographical character: Royal Way of La Mesa (GR 101). This choice takes into account the tradition of geographical itineraries as an outstanding practice in intellectual currents that promote the contemporary appreciation of nature and landscape (García, 1997; Ruiz, 2002). This Royal Way, in its somedan strecht, offers an especially appropriate development to understand the organization of landscape by providing, thanks to its route through the culmination of La Mesa sector, a privileged, almost aerial view of Somiedo and especially the Saliencia Valley and its southwestern slope.

In order to identify the best observation points we performed a Viewshed Analysis using QGIS. For this purpose, an elevation raster and a point vector layer are needed. Elevation data were gathered from National Center for Geographic Information (CNIG). Four different files were obtained from the Digital Terrain Model with 5 meters grid spacing: MDT05-ETRS89-HU29-0051-LID.ASC; MDT05-ETRS89-HU29-0052-LID.ASC; MDT05-ETRS89-HU29-0076-LID.ASC; MDT05-ETRS89-HU29-0077-LID.ASC.

From merging these files, a new digital elevation model (DEM) was created. The point vector layer was generated by extracting nodes from the polyline recorded, following the track with a GPS device. All the spatial data are provided in ETRS 89 UTM zone 29N, the projection and coordinate system for the western part of Iberian Peninsula. The Viewshed Analysis was performed using the plug-in developed by Čučković (2016). From each point of the track, a binary viewshed analysis was carried out. The cumulative output raster (Fig. 1) shows the intensity of landscape exposition from the observation points.

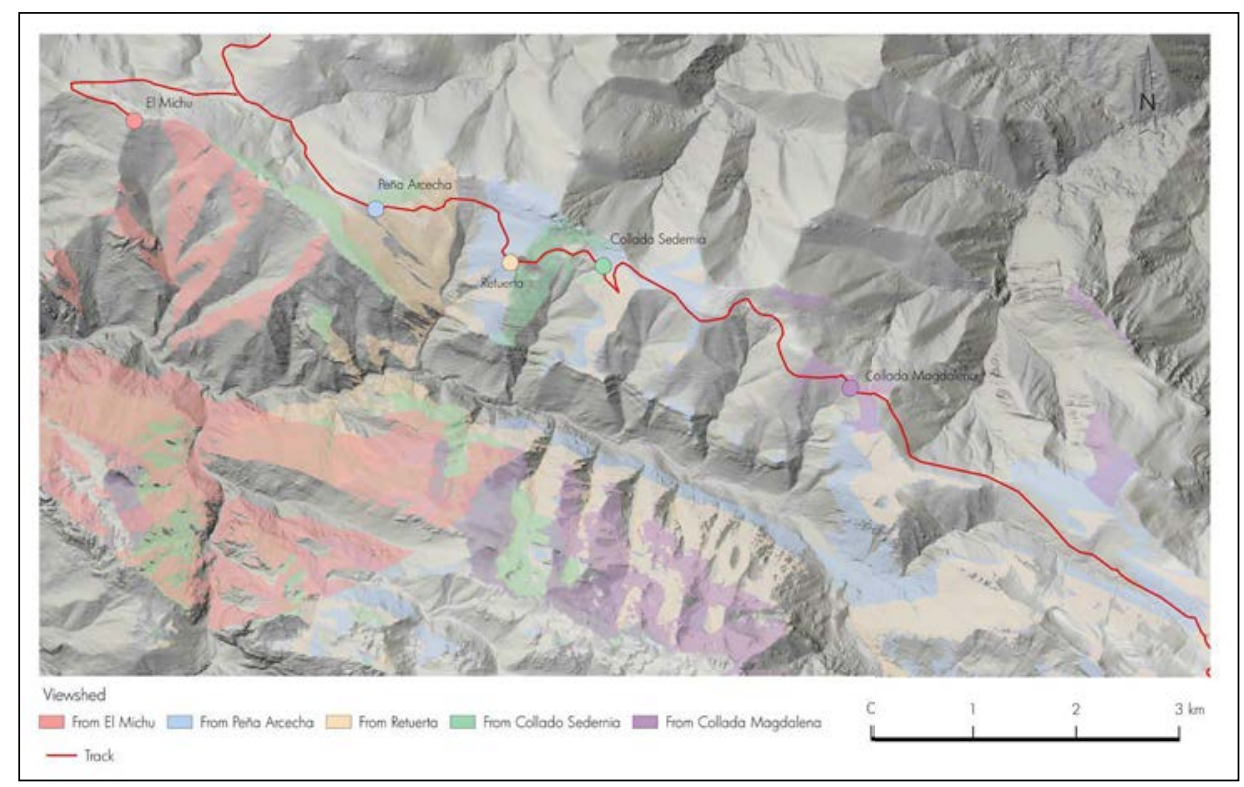

Figure 1. Cumulative Viewshed Analysis. Own elaboration. 
Carrying out fieldwork has demanded complementary tasks as aerial photography treatment and elaboration of other graphic materials. Google Earth tool, which supports tilting the viewing plane or modifying the orientation of images with respect to magnetic north, along with changes in scale and the possibility of generating three-dimensional views, has been useful. In addition, introducing photographs from different dates and the option of superimposing images from diverse sources, facilitates the diachronic analysis (Sevilla and Rodríguez, 2015). Thus, a special effort has been made to illustrate each of the key points in the itinerary with images. In these figures, apart from including historical and current photographs, the outstanding heritage issues are indicated in detail. We have used different font sizes, as well as lines of different thickness or color in order to rank and order the information.

\section{Results}

\subsection{Landscape keys of Saliencia Valley}

Analyzing the value of the study area involves understanding the keys that define and distinguish its landscape. Emphasis has been placed on explaining their morphostructural organization and highlighting the importance of the Appalachian relief forms, as this aspect determines, in the first instance, the physiognomy of this mountainous area. Other fundamental issues are also studied, such as the marked dissymmetry between the two slopes of the Saliencia Valley (determined by the influence of orientation in current and above all past modeling processes and in the distribution of vegetation). Finally, the importance of the traces due to the traditional livestock exploitation is exposed. It has left its mark both in the organization of the territory and in the presence of brañas 1 with different configuration, associated with different types of transhumance that are still partially in force.

\subsubsection{The trascendence of Appalachian forms}

In order to understand the landscape organization of Saliencia Valley it is essential to consider, firstly, the relief configuration and the important role played by the rocks and its tectonic disposition, that is, its internal structure (Muñoz, 1977). As in the Asturian Massif (Rodríguez, 2017), the configuration of the structural frame is the result of a long geological history that has left its mark, in a perfectly recognizable way, in the general layout of valleys and mountains. The rocky outcrops of this sector which belong, from the geological perspective, to the Fold-and-thrust belts region appear ordered in parallel bands of different resistances (quartzite, limestone, slate and sandstone), extending from southeast to northwest accordingly

1 The term braña is used in the sense that the dictionary Toponimia asturiana. El porqué de los nombres collects (García, 2018), as a grassland area of communal use in the high mountain areas, not being circumscribed therefore its meaning to the habitat space (presence of huts and corros) and the surrounding area, as defended by other researchers (Álvarez et al., 1990). This term is also used in Somiedo to refer to the vaqueiran summer villages or equinoctial brañas in which, together with the areas of communal pasture, privately owned meadows (enclosed with walls of dry stone) also appear circling the teito huts. 
with the general disposition of the syncline of Saliencia of which it forms part. The region was modelled due to the erosive processes of its geological structure, and more specifically of its lithological heterogeneity. Consequently, an Appalachiantype morphology was produced. The most resistant materials (the Caliza de Montaña limestone formation at the culmination on the central platform or plateau, the Santa Lucia limestone formation, the ferruginous sandstone of San Pedro and the white quartzite of Barrios formation, in the northeast, that is, in the range of La Mesa) constitute the framework of the external ridges. At the same time, the internal slate core (shales and sandstones of the Huergas formation) was emptied producing the modelling of the subsequent Saliencia wide corridor (Muñoz, 1977, 1980, 1982, 1986). Afterwards, during the Quaternary, the erosive processes triggered by the ice tongue that flowed through this valley, fed from the culminating platform of Las Duernas, contributed to perfecting, but only in detail, the U morphology already configured in essence as result of differential erosion performance (Fig. 2) (Castañón, 1989; Rodríguez, 2015).

This example constitutes the best place in the Cantabrian mountain range in which this type of structural forms can be better recognized (Criteria vii and viii: Repr., Aest./Sce., Cons. indicators ${ }^{2}$ ). A fact that would justify the linkage of this territory with the International Appalachian Trail, an international-level hiking project that aims to join all the areas of the World that have this type of mountains: United States, Canada, Greenland, Ireland, Scotland, Wales, Norway, France, Spain, Portugal and Morocco. The idea of the IAT project (International Appalachian Trail, Barron et al., 2016) is to establish a Spanish-Portuguese path that extends from one end of the Iberian or Hesperic Massif, from Asturias and Galicia to Córdoba, passing through the north of Portugal, and using the historic ways. Somiedo and the Royal Way of La Mesa seem to fit to this approach. It would complete the institutional recognition and international projection of Somiedo derived from its inclusion in several international networks (SPA Somiedo, SCI Somiedo and Biosphere Reserve) (Crit. vii, viii and $\mathrm{x}$ : Prot.), adding a new variable, its morphostructural organization, to the multiple values aforementioned (cultural, animal and vegetable biodiversity, glacial landforms, etc.). Therefore, the value of the Royal Way of La Mesa would be enhanced, although it is already very popular and widely recognized both from the institutional point of view and by hikers, travellers and scientists who have long shown his interest in this traditional communication path and its environment (Crit. vii, viii and $\mathrm{x}$ : Ag.). Testimony of its importance is the existence of numerous informative publications (e.g., Peyroux, 1992; Mañana, 2011) or its analysis in numerous doctoral theses and scientific contributions (e.g., Sánchez, 1972; Madrazo, 1977; Quesada Alonso et al., 1993; Alba, 1999; González, 2011; Pisa, 2015) (Fig. 3).

2 A link between the key information of territorial features and the indicators validating compliance with UNESCO criteria (codified abbreviation in Table 2) is established in this section. 


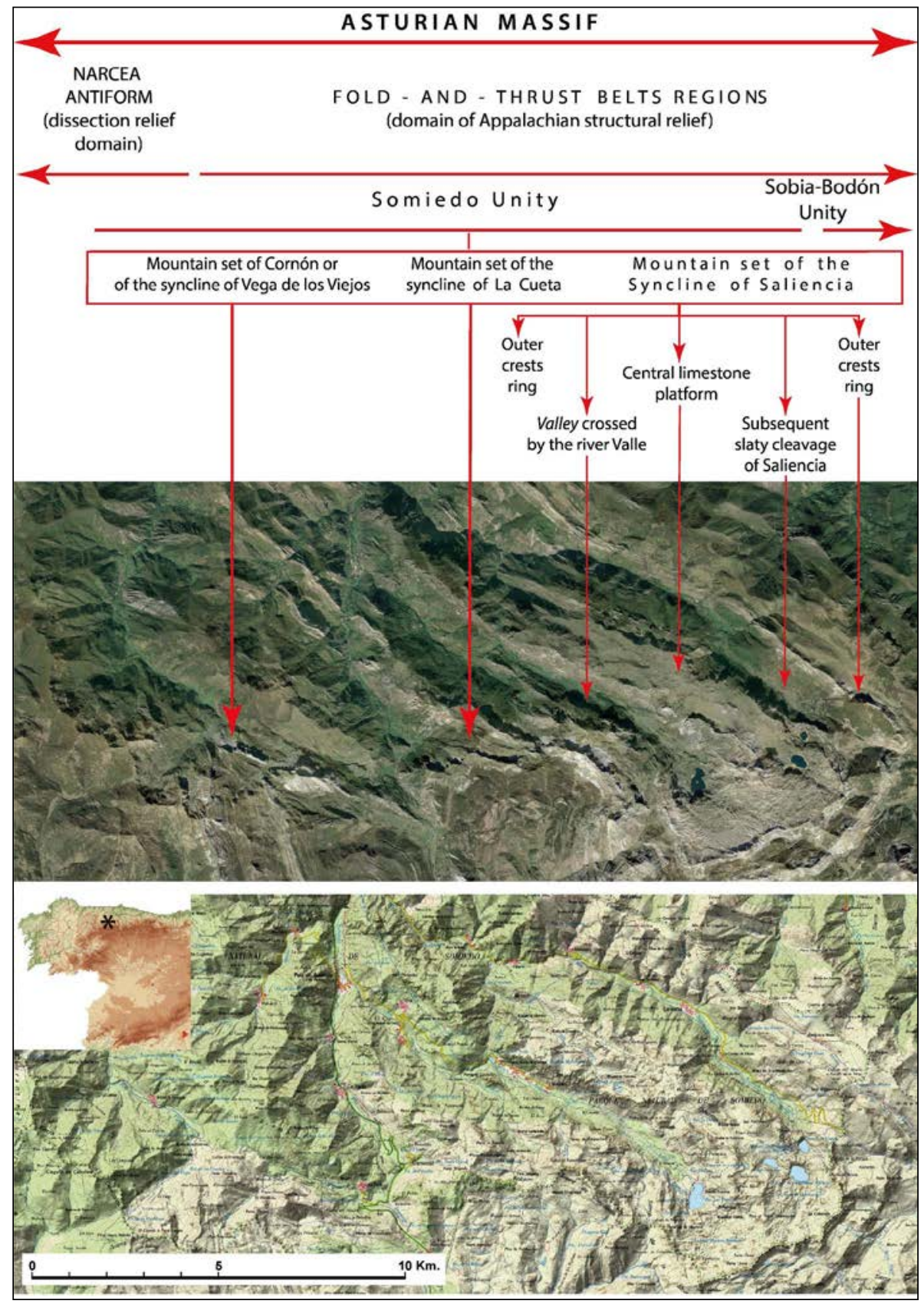

Figure 2. Illustrative scheme of the Fold-and-thrust belts region, with indication of the morphostructural units that make up the mountainous set of Saliencia Syncline. Source: Google Earth image (2017) and National Topographic Map of Spain, scale 1: 50,000 (available at: http://www. ign.es/iberpix $2 /$ visor/). Own elaboration. 


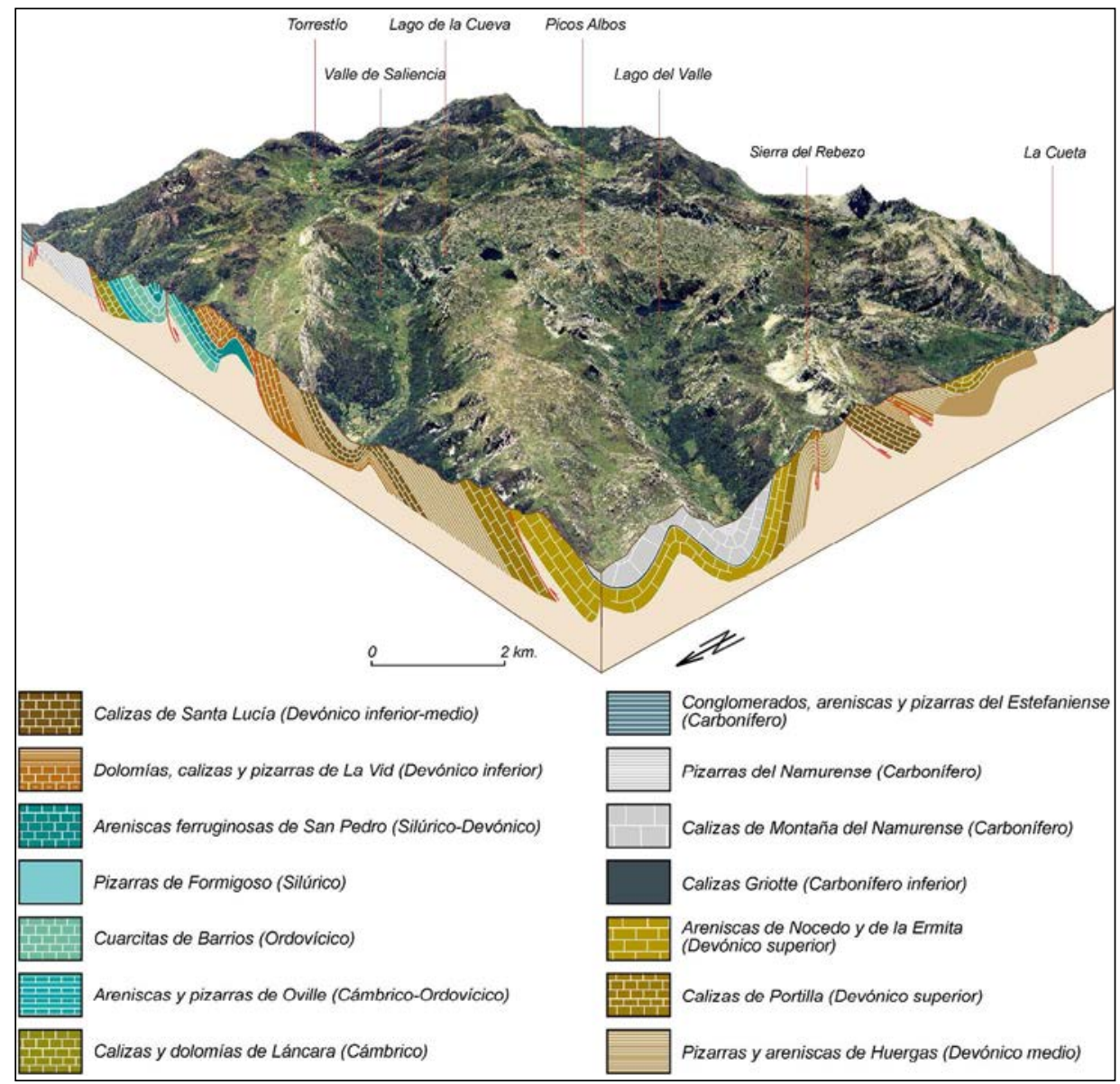

Figure 3. Block-diagram of Saliencia mountainous area showing the influence of internal structure (lithological variety and folded arrangement of the rock) in the relief organization. Source: Fernández Cuesta et al., 2005. Elaboration: Juan Carlos Castañón.

\subsubsection{The landscape diversity marked by the dissymmetry of slopes in Saliencia Valley}

The presence of glacial forms in the areas of higher altitude and the importance of the periglacial events in the study area, confer to this space a great landscape diversity that makes it especially attractive (Crit. vii and viii: Div., Aest./Sce.). Because of its geomorphological configuration, the massif of the Saliencia syncline, has been one of the areas of the Cantabrian range most studied by several scholars (HernándezPacheco, 1929; Muñoz, 1977, 1980, 1986; Castañón, 1989; Menéndez, 1994) (Crit. vii and viii: Ag.). The contributions of Muñoz deserve especial recognition because, apart from including a clarifying exposition about the morphostructural organization, his works answers some key questions regarding the glacial action. As the perfect 
adaptation of the ice tongues to the pre-existing topography, the verification of traces corresponding to a single glaciation or the establishment of the lower threshold of moraine evidences around a thousand meters of altitude. The doctoral theses of Castañón (1989) and Rodríguez (2008) have been an advance in relation to the glacial manifestations inherited from the Pleistocene. Both evidencing the interest of the of the relief organization of this sector, that already was pointed out by Francisco Hernández-Pacheco (1930) on the occasion of the excursion he made through the western mountain passes of the Cantabrian range.

The institutional recognition of the landscape of Somiedo also emphasizes this aspect of the natural environment, indicating in the natural park declaration document that "...Such wealth in geomorphological forms translates into an equivalent wealth in soils and, therefore, habitats, ecosystems and species" (Gobierno del Principado de Asturias, 2018a) (Crit. x: Div., Cons., Prot.). Besides, landforms of glacial origin such as the lakes of Saliencia (La Cueva, Calabazosa, Cerveriz and La Alamgrera), the Lago del Valle, as well as the high mountain area located between these lakes (the Massif of Picos Albos) they are also included within the Network of Protected Spaces of the Principality of Asturias as a Natural Monument (Somiedo Lake system). These lakes also are included as Point of Interest in the Spanish Inventory of Geological Sites of Interest elaborated by the Spanish Geological Survey (IGME) (Crit. vii and viii: Prot., Ag.). It can not be ignored either that in the early institutional recognition of the municipality of Somiedo influenced the great variety of animal species, being the most emblematic the capercaillie and the Cantabrian brown bear (there is one of the main cores of the Cantabrian Mountains). Moreover, almost half a hundred species of mammals have been catalogued in Somiedo. Among the most interesting ones, the wolf, the piornal hare, the Pyrenean desman and the otter stand out. In addition, more than one hundred species of birds have been catalogued, among which the goshawk, the peregrine falcon or the eagle stand out for their protection (part of the western nucleus of the golden eagle nesting is integrated). Together with the extension of deciduous forests and the existence of numerous endemic plant species, it is a clear indicator of the environmental diversity of the municipality of Somiedo and of the excellent conservation of its natural environment (Gobierno del Principado de Asturias, 2018a) (Crit. x: Div., Repr., Cons., Prot.).

The value of these aspects of the natural environment justifies the integration of this territory, in the year 2000, into the European network nature protection areas Natura 2000, being declared a Special Protection Area for Birds (SPA ES 0000054) and a Site of Community Interest (SCI ES 0000054). This year Somiedo received its last institutional recognition when it was declared Biosphere Reserve, within the Man and Biosphere (MAB) program of UNESCO (Crit. x: Prot.). Precisely in the Declaration document highlights some of the outstanding features of this territory, indicating, "It contributed to the improvement of the quality of life of its population. In addition, given its extraordinary degree of conservation, numerous research works related to natural resources have been carried out in this territory and a large number of activities have been performed in the field of environmental education (Crit. vii, viii and x: Cons., Ag.). The MAB Committee took into account that "to its high degree 
of conservation are added an originality and environmental diversity and unique landscapes, also harbouring an important cultural and human heritage" (Crit. vii and x: Div., Aest./Sce., Cons.). It is also recognized that the conservation of Somiedo "also fosters the conservation of a rich cultural heritage derived from the ethnographic wealth of its populations, which have managed to preserve traditional forms of exploitation of resources respectful of them up to the present day" (Crit. iii, iv and v: Ad., Anc., Cons, Prot.).

Focusing on the characterization in the Saliencia Valley, the landscape diversity is seen, at this scale of analysis, increased because of the influence of a new variable, the orientation, which explains the marked contrast offered by its two slopes (Fig. 4) (Crit. vii and viii: Div., Aest./Sce.). The sunny slope presents a relatively uniform aspect. It is possible to reconstruct easily the outline of the rocky outcrops, especially in its upper half, formed by the limestone of Santa Lucia formation, opposes the irregular shady slope, in which the clear glacial forms have cut the outer limit of the culminating calcareous platform, providing a scalloped longitudinal profile (Muñoz, 1986; Castañón, 1989). In the northern alignment, the absence of glacial landforms has allowed the dominance of structural lines, especially at its southern end. It is possible to recognize easily the continuity of the rocky outcrops, extended from southeast to northwest, only interrupted by short anaclinal incisions that, taking advantage of the transversal fracture lines, which produces, when reaching the most resistant materials, to small and deep incisions called escobios.

On the opposite slope (southern) the magnitude of the glacial morphogenesis explains the presence of a series of cirques, clearly drawn and oriented northwest, at the foot of the Tarambico mountain range, accompanied by important and varied surface formations also of glacial origin (Crit. vii and viii: Mag./Int., Aest./Sce.).

This different configuration is probably due to morphoclimatic-type issues, derived from a more favourable exposure to snow accumulation and maintenance processes in the shady slope, to structural causes. Specifically, its overfeed from the upper calcareous plateau, as evidenced by the identification of abrasion traces derived from the ice creep on the backs of glacial cirques and on the margins of the upper surface of the aforementioned Tarambico Ridge, located above 1800 meters of altitude. This ridge should have worked, therefore, as an area of ice accumulation that later overflowed to this slope (Rodríguez, 2015).

In the inner side of these semi-circular glacial forms or niche glaciers, the forms of erosion (avalanche channels, glacial overdeepening lakes or tarns, and rocky thresholds in its bottom) share space with huge periglacial scree slopes. These slopes are crossed by wandering streams, producing, downstream, small snow moraines and, more infrequently, incipient rocky glaciers, whose heterometric composition dominates the large blocks of limestone. 


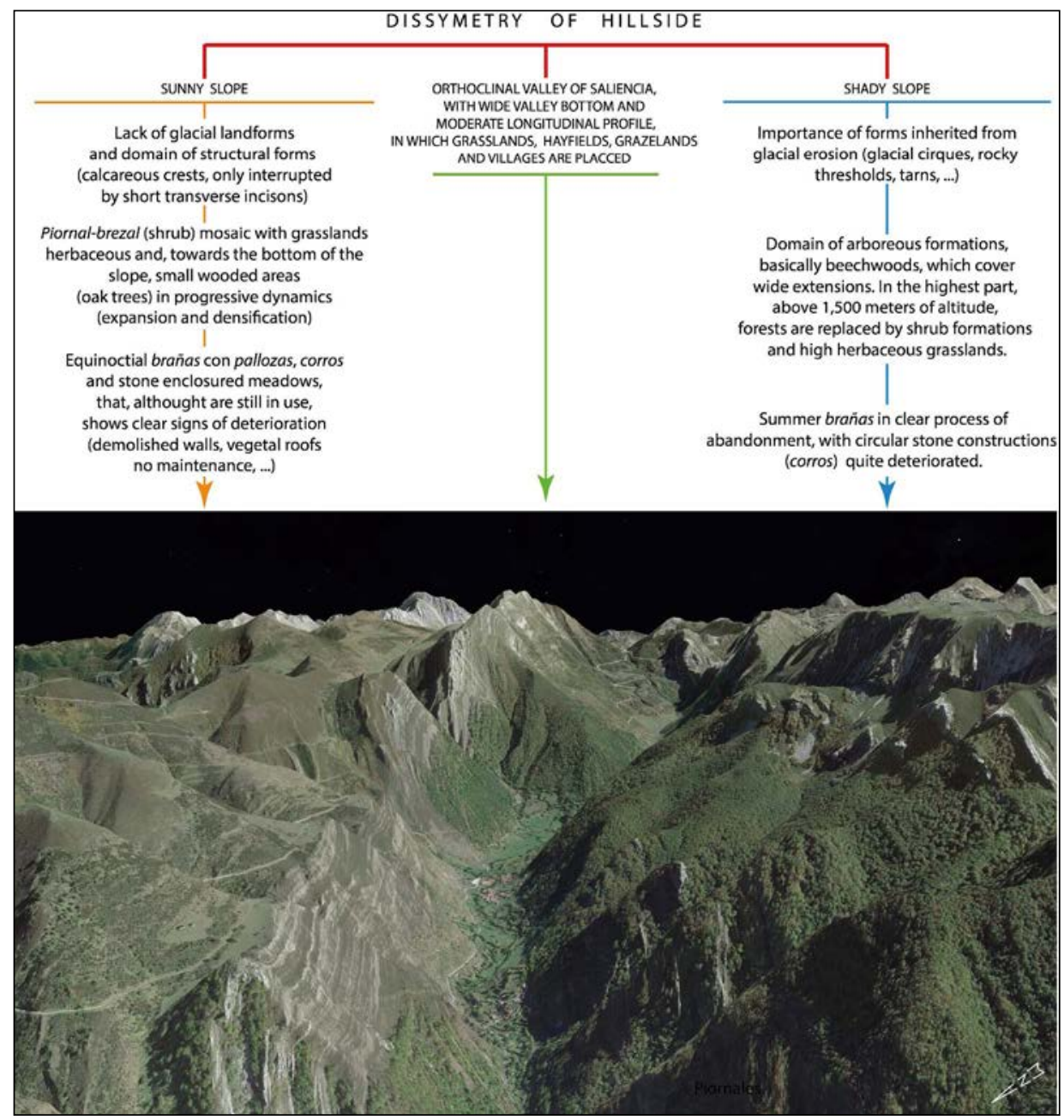

Figure 4. Marked dissymmetry between the slopes of Saliencia Valley. Source: Google Earth image (2017). Own elaboration.

The organization of the vegetation cover again underlines the marked contrast between both slopes. On the sunny slope, the supremacy corresponds to the scrub formations dominated by the piornos (Genista florida ssp Polygaliphylla), the broom (Cytisus scoparius) and the heather (Erica australis), which alternate with the grassland areas and, towards the valley floor, with opened formations of hazel trees and small oak groves (Quercus petraea) in clearly progressive dynamics. In the shady slope, to the sub-alpine scrub, the herbaceous formations (cervunal) and the trampled meadows (gleras) in the higher areas, follows towards the lower part, the extensive and closed beechwoods forest, among them Monte Grande and Monte Las Bustariegas are highlighted (Crit. x: Div., Cons.). Precisely, in the Natural Park declaration already 
pointed out the distribution of the arboreal formations, also specifying "the presence of legally protected species such as holly (Ilex aquifolium) or yew (Taxus baccata) (...)" (Gobierno del Principado de Asturias, 2018a) (Crit. x: Prot.). Thus, the structural, geomorphological and biogeographical diversity existing between the two slopes of the Saliencia Valley, reinforced by the different uses carried out by man is reflected in a clear landscape contrast between the two hillsides (greater simplicity of the sunny slope with respect to shade, which is more heterogeneous). Thus, in the latter, the culminating area corresponds to the most rugged strip of the whole, being integrated by a succession of glacial cirques, received in front of the layers of limestone and separated from each other by abrupt rocky ridges. The rugged aspect of this culminating fringe is due to, the sparse vegetation cover, confined in the most sheltered enclaves, where they are interspersed between the slopes deposits such as rocky glaciers and scree slopes where sub-alpine scrubs and herbaceous formations are placed. These spaces, due to the difficult access, their intricate relief and the poverty of the pastures that cover them, had undoubtedly a very marginal livestock exploitation, being limited to the lesser slope of the mountains sheltered in the glacial circus recesses or niches. In some of them, remains of the old circular stone constructions (corros) that gave shelter to the cowboys during the summer months are still being preserved (Crit. iv and v: Rar/Res., Anc., Cons.). Downstream, in the beech woods of La Bustariega and Monte Grande, the dominant plant species forms extensive and closed forests that are extended until the broad bottom of the valley modelled on the slender inlet of the Huergas formation, accompanied by the fluvial and torrential incisions that run along the hillside and the occasional presence of rocky outcrops. The use of this arboreal formation had to be very limited in the past, since otherwise it would not have reached our days with the aspect it offers. For this reason, its conservation both for the need to manage a scarce resource and for its essential function protecting the village of Saliencia (since it prevents it from being affected by hillside movements) is justified. In the Natural Park regulation use rule, this slope is included in the zone of special restricted use with the aim of guaranteeing its conservation, excluding, in addition to any extractive activity and hydroelectric exploitation, the tourist use (Crit. x: Cons., Prot.).

On the opposite slope, the landscape units also offer an organization in altitudinal belts, although all of them have as a common denominator the absolute dominance of the shrub formations (broom, heather, ...) and herbaceous, caused by a cattle pressure on this slope much more intense and still largely in force (Crit. v: Magn/Inten., Ad., Cons.). Thus, in the culminating part, in the unit identified as "Riegas, brañas and piornales", the presence of a succession of equinoctial brañas, made up of cabanas de teito and meadows enclosure by stone walls is striking. They are located on the hills developed above the rows of limestone of Santa Lucia formation, taking advantage of the goodness of the pastures (Crit. iv and v: Rar/Res., Aest./Sce., Ad., Anc., Cons.). Below, linking to the bottom of the valley, there is a band in which the thin outcroppings of mountain limestone alternate with small extensions occupied by a shrub cover of reduced size and average density that scarcely covers the underlying rock (carba). Undoubtedly, this aspect must be related, in addition to the natural constraints (especially the influence of the orientation of the slopes), with the traditional management of the territory and, more 
specifically, with the greatest livestock pressure (Crit. v: Mag./Int., Ad.). In any case, this situation seems to be redirected in recent decades, especially at the junction of this slope with the bottom of the valley, where a clearly progressive vegetation dynamics is seen, especially evident in the small oak tree stands.

\subsubsection{The traditional livestock use as a distinctive element: the inheritance of transhu- mance}

Along with physical features, the traces left in landscape by the agro-livestock activities are of special importance, being possible to recognize different modalities of transhumance typical in Iberian Atlantic mountain (Crit. v: Div., Repr., Aest./Sce., Anc., Cons.). In addition, unique constructions associated with these farming practices have been preserved: the cabanas de teito. Somiedo is one of the few places where these constructions are still preserved in quite adequate conditions. The municipality has almost a hundred brañas with cabanas de teito, corros and the rest of associated elements, resulting from different types of transhumance that have coexisted in the Cantabrian range. They form a complex cultural component with economic, social and ideological significance (García, 2011) (Crit. iv and v: Magn/Inten., Div., Repr., Rar/ Res., Anc., Cons.).

Bearing in mind that the landscapes linked to livestock activity in the Cantabrian range have been in a process of being abandoned, more or less widespread, for too long and that part of their identity is "eclipsed, swallowed by bushes and shrubs" (Corbera, 2016), the survival of the brañas with cabanas de teito in Somiedo, together with other elements (fenced meadows, fountains, fresqueras) acquires greater importance (Crit. iv and v: Repr., Rar/Res., Aest./Sce., Anc., Cons.). Even in the official documents to constitute the Somiedo Natural Park it is considered that the cabanas de teito are closely related to those that had to conform the primitive pre-Roman settlements (Gobierno del Principado de Asturias, 2018a). These issues were also taken into account in the declaration as a Biosphere Reserve (Gobierno del Principado de Asturias, 2018b) (Crit. iv and v: Rar/Res., Anc., Cons., Prot.).

As it could not be otherwise, the brañas have long called attention, and there are many documentary references on this subject (Crit. iv and v: Ag.) Without pretending to make a systematic mention of these works, it is worth remembering some of the most important ones, such as that made by Jovellanos in 1792, alluding to abundant cattle in the grasslands of La Mesa (Caso et al., 2011).

Another significant mention is due to Fritz Krüger, German linguist and ethnographer from the University of Hamburg, who in the autumn of 1927 toured the southwestern Asturian region, collecting material about settlement and traditional ways of life for the writing of his doctoral thesis (Krüger, 1948); in his work he mentions the brañas and their constructions with vegetal roof (Krüger, 1948). Francisco Hernández-Pacheco also records the importance of transhumance in Saliencia in those years. He collects information about the geographical origin of sheep flocks, mentioning a conversation with a shepherd coming from Extremadura (Hernández-Pacheco, 1930). 
The most complete contributions about the importance of transhumance in Somiedo has been made by the anthropologist Adolfo García. After publishing his doctoral thesis (García, 1988), he continued to pay attention to this subject (García, 1995, 2003, 2009, 2011; Concepción et al., 2008). Between 1993 and 1999, he designed, launched and directed the Ecomuseum of the Somiedo Natural Park (Ayuntamiento de Somiedo, 2018). He was also the coordinator of a European LIFE project (1995-1996) for the integrated and sustainable recovery of brañas in the Somiedo Natural Park (García, 2011). In 2009, he directed a new project consisting of an inventory and a detailed diagnosis of the state of the cabanas and corros, proposing an action plan that would guarantee the conservation of most of this valuable heritage (García, 2011) (Crit. iv and v: Cons., Ag.). It is a fundamental knowledge transfer, to which other enriching contributions are added, like those of José Alba. From his specialization in Applied Economics, he has worked on the potential of Somiedo protection for socioeconomic development. He has paid attention to the possibilities of a tourism development that respects environmental and ethnographic values (Alba, 1996, 1999, 2012).

Transhumance has had a transcendental importance in the organization of the extensive use of mountain, adopting diverse modalities that have left their own mark in the form of constructions, roads, enclosures ... The delivery of the Exemplary Town Prize to Villar de Vildas by the Princess of Asturias Foundation in 2004 came to recognize the relevance of its cultural heritage, especially the vaqueiran brañas (explained below). An excellent autochthonous bovine race (called De los Valles) was maintained in Somiedo at the time when other foreign races were introduced in Asturias. The neighbors have undertaken an adequate transformation of the livestock sector. And they are in charge of the conservation of the cabanas de teito, being one of the traditional trades of Somiedo, which has allowed the maintenance of the ethnographic heritage. In fact, in the brañas of Villar there are some 65 cabanas in perfect condition (Fundación Princesa de Asturias, 2018) (Crit. iii, iv and v: Magn/ Inten., Repr., Rar/Res., Ad., Anc., Cons., Ag.).

Somiedo has been for centuries a territory where all types of transhumance existed thanks to its orography, its climatology, its natural resources and its location: the interior or short radius one, the long radius one (from North to South, also called de vaqueiros de alzada) and the one from South to North or Mesteña (Fernández, 1992; García, 2011).

Transhumance of short radius, or trasterminant, is the most common and takes place between the valleys of southern Asturias and the mountains. When spring arrives, the cattle moves to the intermediate or equinoctial brañas where they graze in collective spaces (in some cases staying overnight in fenced meadows and receiving one or two rations of dried grass). There are daily movements of the shepherds from the village to the brañas to milk and tend the cattle. Its distinguishing feature is the presence of fenced meadows, privately owned, with stone walls, fountains and carriage road. The majority of the somedan brañas belong to this category (Mumián, La Corra, Las Morteras de Saliencia, Fuexu, La Pornacal, Perlunes, Montrondio, La Raíz...). The buildings are 
larger, with a rectangular floor plan and a broom deck, usually with a block in the lower part and a barn or loft above (Álvarez, 2001; Linares, 2004; Graña and López, 2007). In some cases, agricultural use was also carried out: wheat, rye, barley, lentils and even some orchards with potatoes and vegetables.

At the end of spring the cattle climb to the high or summer brañas (located between 1500 and 1800 meters), requiring less constant care (and coinciding with the hardest work dates for shepherds or owners). They are the most primitive and simplest brañas; there are no enclosed spaces or private properties: grassland areas are for communal use. The constructions associated with the summer brañas (called corros) are also very simple. They are small buildings usually circular, with plant cover or false stone vault covered with tapins. They do not have stables or haylots and are used as shelters for the brañeiro. They are interpreted as a very archaic and extensive way of exploiting space. Finally, at the beginning of autumn the cattle return to the intermediate places (equinoctial brañas) and at the end of the fall they finally go down to the village and settle down (García, 1988) (Crit. iv and v: Repr., Rar/Res., Aest./ Sce., Ad., Anc., Cons.).

Transhumance of long radius (or simply transhumance) is carried out between the area near the coast and the higher zones, having passed through two periods: until the 16-17th centuries it was controlled by the monasteries and lately by the nobility; from that date it became the activity practiced by the vaqueiros de alzada, livestock communities that have always aroused great interest among historians, geographers and anthropologists for their identity, economic and territorial management peculiarities (Uría, 1976; Feo, 1980, 1985; Sánchez, 1988; Cátedra, 1989) (Crit. iii: Rar/Res., Anc., Ag.). From Pravia, Cudillero, Las Regueras, Siero, Llanera, Oviedo, Salas, or Miranda, cattle moved to the brañas or villages located in Somiedo, or Babia and the head of the Sil Valley (León). The denomination de alzada has to do with the fact that they moved towards the southern Asturias during the summer establishing their settlement at higher altitude. In May, the vaqueiros used to close their winter residence to move to the brañas where they stayed until October (Crit. iii: Ad.).

Traditionally they were considered as a closed social group, with inbred character, that preserved their singular customs and folklore throughout the centuries. These features led to their marginalization and discrimination on the part of the Church and the Xaldos (a term coined by the vaqueiros themselves to designate sedentary farmers). But it also favored the survival of one of the most unique cultures in Atlantic Europe (Crit. iii: Rar/Res., Anc., Cons.). There are still vaqueiros that come in the summer months to Somiedo from Salas or Belmonte de Miranda (at present they use motorized vehicles). As a result of this form of transhumance, unlike other places in the Asturian mountains, true villages linked to this movement of livestock, with farmland, fenced meadows and houses were formed. Perlunes (in part), La Peral, Llamardal, El Puerto and La Falguera are summer vaqueiran villages (Figs. 5 and 6). All of them are located at more than 1000 meters (Crit. iii: Rar/Res., Aest./Sce., Ad., Anc., Cons.). 


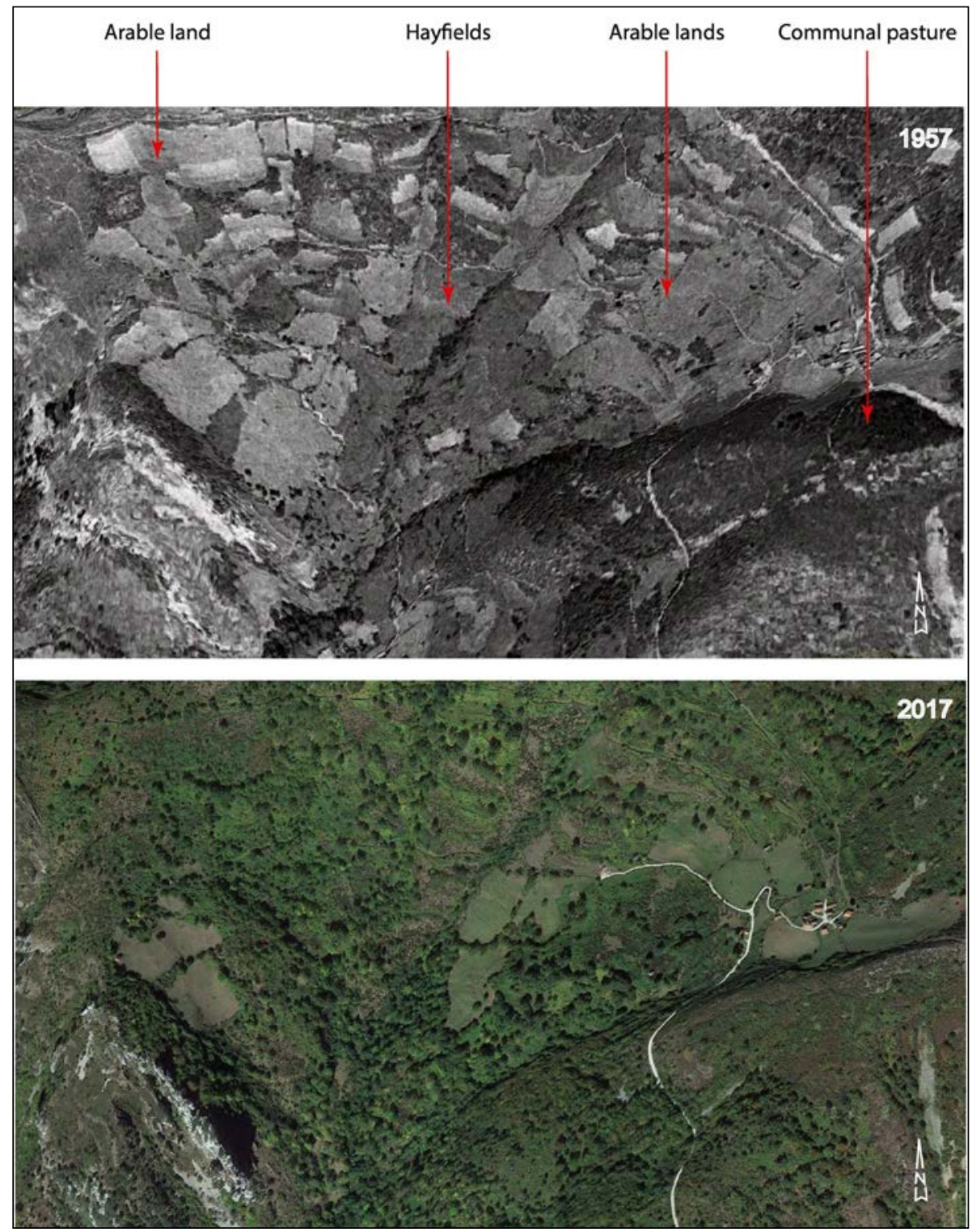

Figure 5. Vaqueiran braña of La Falguera, located in the southern slope of La Mesa ridge, at 1250 meters of altitude. This braña-village, to which the neighbors of Buspol (located in the asturian municipality of Salas) travel every summer, had in the past arable land, hayfields, communal pasture areas, that can be easily identified in the aerial photography of 1957. It can be osbserved the three elements of the traditional agrarian landscape in asturian mountains. On the contrary, in the image of 2017, only a few meadows keep the pasture function. The rest of the space has been invaded, in an accelerated progressive dynamics of the vegetation, by shrub species and arboreal, making the primitive landscape practically unrecognizable. Source: Fragment of Series B flight, frame 53026, taken on July 17, 1957 (upper) and Google Earth image, 2017 (lower). Own elaboration. 
Rodríguez et al.
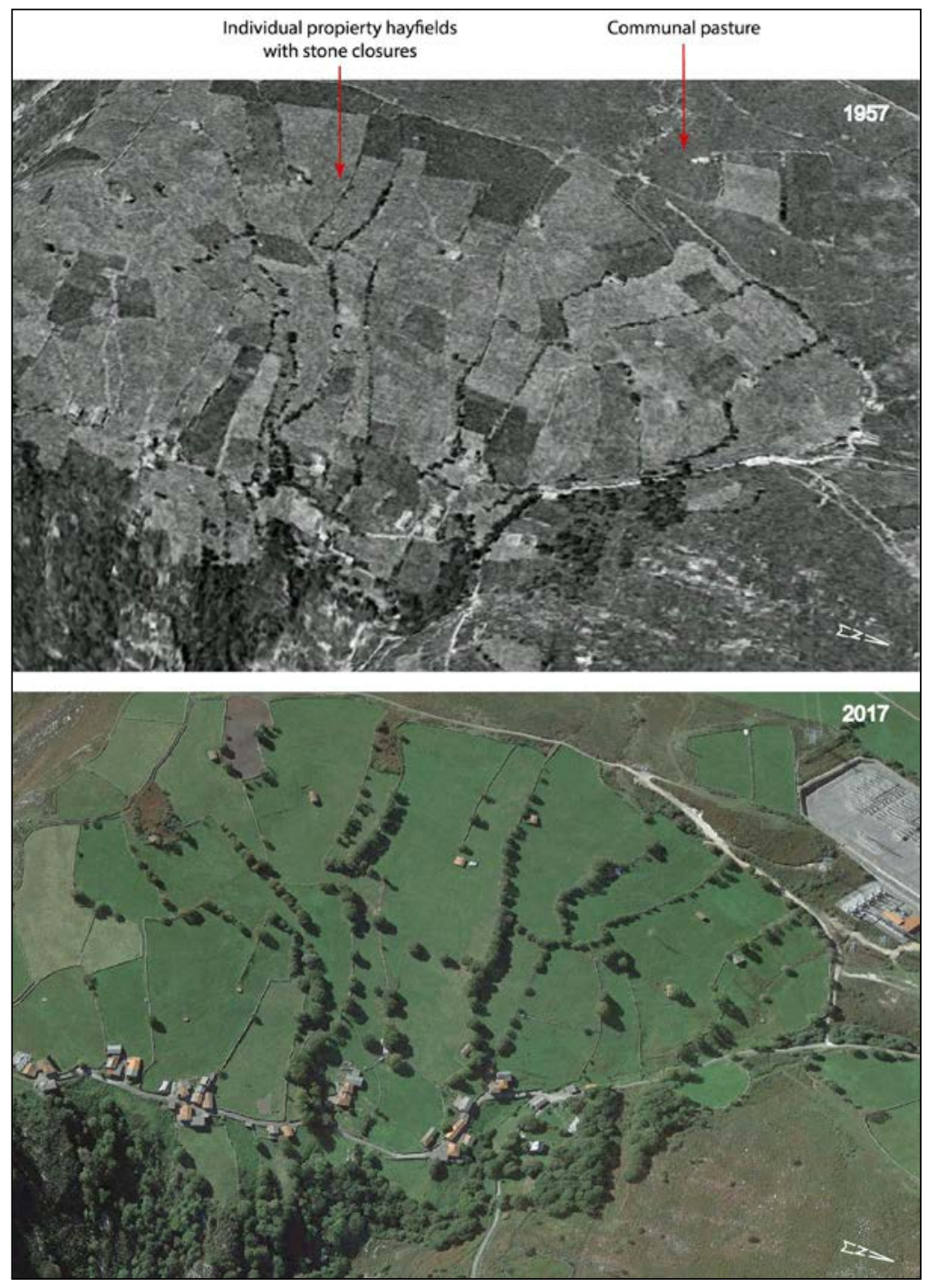

Figure 6. Vaqueiran village of Buspol. Unlike what was observed in the vaqueiran braña of La Falguera, there are hardly any substantial changes in the landscape, drawing attention in the case of the people of Buspol to the maintenance in the 2017 photograph of the livestock space in conditions very similar to those that it offered in 1957, without appreciating clear signs of abandonment neither in the mowing meadows nor in the closures that delimit them. In this sense, only certain changes in the vegetation that accompanies these closures are appreciated, more evident in the recent image, but in no case does it offer the aspect that has been commented with respect to the vaqueiran braña mentioned before. This same situation of stability can also be seen in the areas of communal pasture that surround the closed meadows. Likewise, it is noteworthy, in this comparison with the arable land in summer village, the absence in Buspol of farmland, practically having the whole land a livestock orientation, both in the past and in the present. Source: Fragment of Series B flight frame 57871, aken on August 6, 1957 (upper) and Google Earth image, 2017 (lower). Own elaboration. 
The space owned by the vaqueiros has been exploited in two different ways: the areas closest to the houses correspond to the private properties of the families. They are farmland or mowing meadows. In the past, in these summer villages, only half of the enclosed spaces were dedicated to meadows, the rest were farmland. They sowed wheat, potatoes, peas, lentils, black beans, barley. The rest of the enclosures were occupied by mowing meadows from which dried grass was obtained for spring and autumn. These enclosures occupied in general a minimum part of the space owned by the community. On the other hand, the zones of pasture and low mount, and the crests and rocks, all this undivided property of the neighbors, always represented the biggest surface. These lands were used jointly for pastures, rozas and firewood by all the neighbors, being of capital importance for the group's economy (García, 1988).

There was a third modality of transhumance in Somiedo: the mesteña. During the warmer months, flocks of merino sheep from Babia (León), the closest, or from Extremadura, the most remote, reached the high passes of Somiedo: La Mesta, Tarambico, Las Duernas... At present, this type of movement, documented as early as the $13^{\text {th }}$ century (Fernández et al., 2013), no longer occurs, and this type of smaller livestock has been replaced by cattle. The concentration of cattle in the enclaves with more desirable pastures determines that many hillsides are barely used, which implies a progressive degradation of pastures and the development of revegetation processes (Lasanta, 2010).

\subsection{A geographical-historical itinerary for an exceptional landscape: Royal Way of La Mesa}

The Royal Way of La Mesa was a fundamental route in the communication from pre-Roman times to practically the Contemporary age. Its intensive and continuous use over time, together with the peculiarities of its layout, and its connection to issues of a historical nature such as the passage of Romans and Arabs or having been used by the vaqueiros, turn this historical itinerary into a path with special recognition; what is evidenced at present in its frequentation by mountaineers and walkers. The fact that it was in disuse from the $19^{\text {th }}$ century, displaced by the neighboring mountains passes of Somiedo and Ventana, and above all by the construction of Pajares road, has favored an adequate conservation of its layout (showing the old pavement in certain sections). Even with the necessary transformations that could be carried, it still responds to the consideration of "ancient route", which gives it a special archaeological value (García et al., 1976; Madrazo, 1977; Fernández, 2003; González, 2011).

We have focused on its somedan strecht $(15 \mathrm{~km})$. The works were started in the mountain pass of San Lorenzo and the analysis was developed in NW-SE direction until finishing in the pass of La Mesa. The result is exposed through explanatory images of the various elements that can be recognized at each geographic point of interest in relation to the landscape keys: View over La Falguera, an example of vaqueiran braña (deviation from Piedraxueves towards Punta del Michu on N-S subsidiary route) (Figs. 5 and 6); The transcendence of the Appalachian landforms (Fig. 7); La Corra, an 
example of equinoctial braña (Fig. 8); The marked dissymmetry between the slopes of Saliencia Valley (Figs. 9 and 10); Views on the morteras of Saliencia, on the dynamics of traditional agrarian landscape (Fig. 11); Braña of La Mesa, an example of summer braña linked to Mesta (Fig. 12).

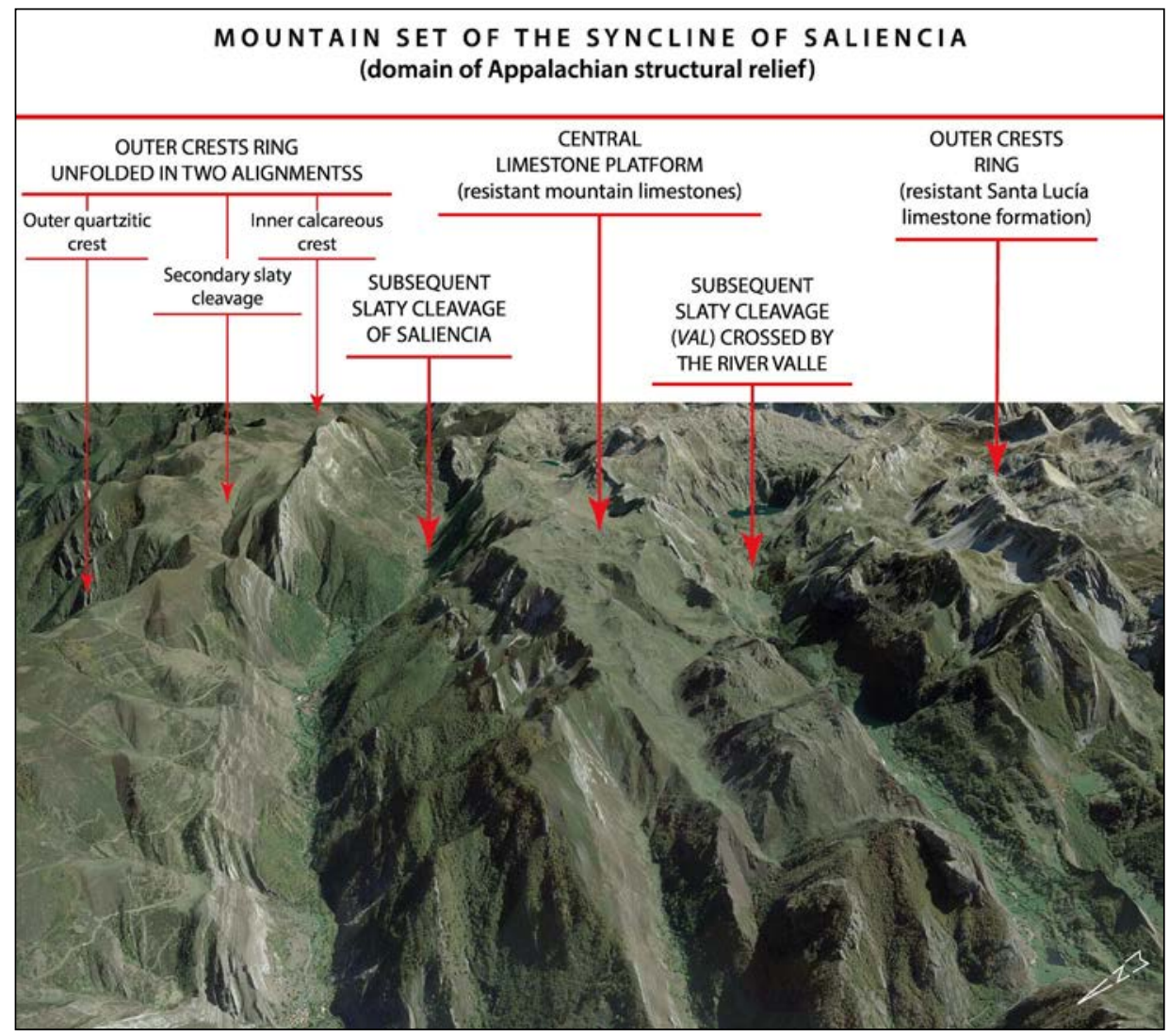

Figura 7. The transcendence of Appalachian landforms. This relief has been modeled on an old folded structure (Paleozoic Basement) that was leveled at the time by the erosion processes that occurred during the Mesozoic period. Then, the alpine tectonic movements, responsible for the lifting of the old Hercynian thrust faults and, as a consequence of it, the excavation and evacuation of the most brittle materials, determined the configuration of an Appalachian type relief, in which the quartzite and calcareous outcrops became the most important orographic alignments, while the dismantling of the levels of more brittle slates favored the formation of extensive depressed subsequent basins, that is, perpendicular to the dip of the layers; later these valleys (Saliencia and del Valle) were retouched, although only in detail, by the passage of glacial tongues, fed from the culminating calcareous platform. Source: Google Earth image (2017). Own elaboration. 
High limestone platform pierced by glaciokarstic depressions, covered at the bottom by

grassland (vegas), and separated by residual reliefs of conic profil (cuetos), with ruiniform karren and covered by sparse sub-apline shrubs (juniper, berries, heath...)
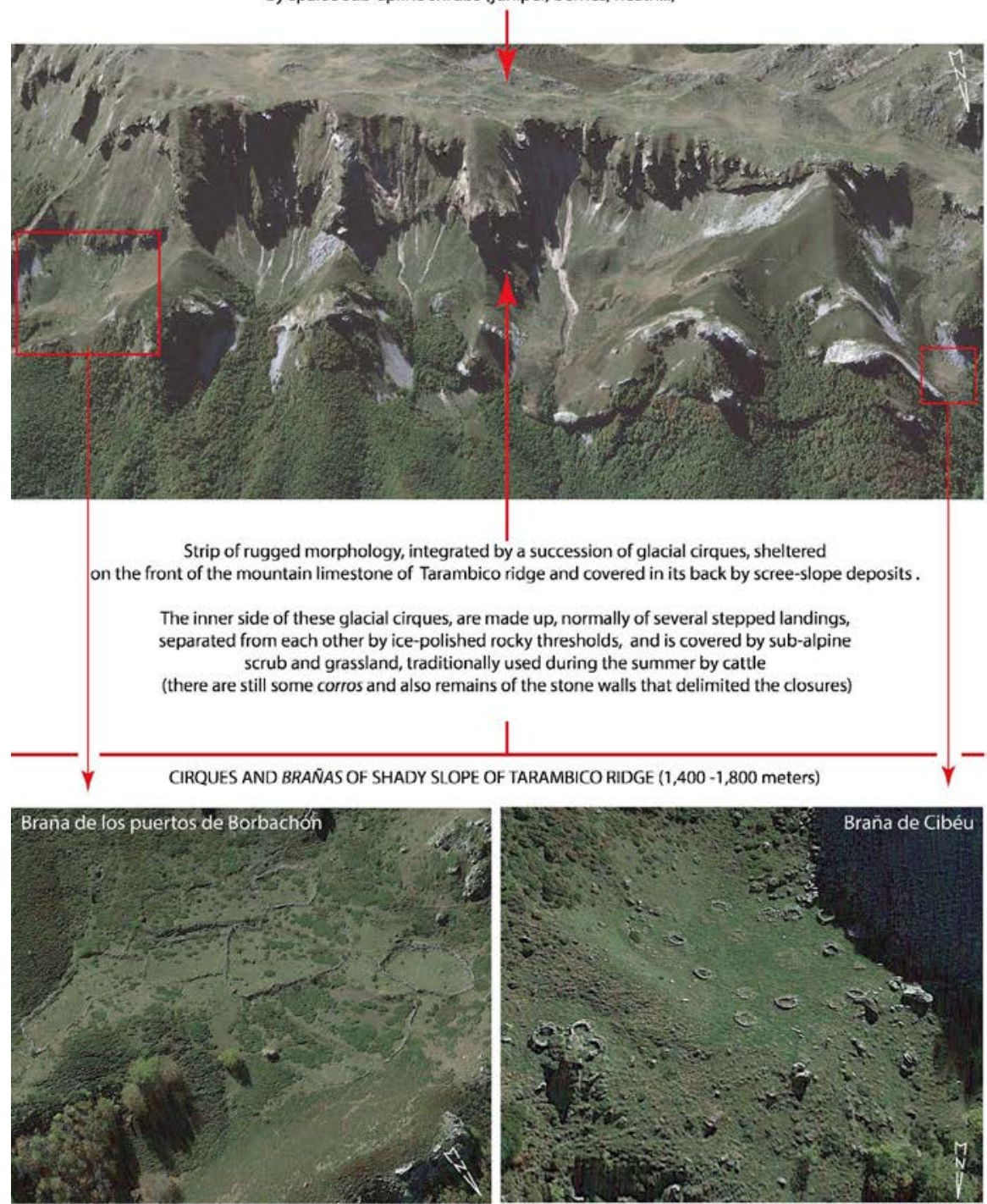

Height summer brañas: located at more than 1,500 meters of altitude, in the shady slope, and quite distant with respect to the villages from where the cattle went up. Its use was limited only to the summer months. The grass was used collectively, although in the ports of Borbachón it could be see the stone walls that delimited some meadows, which indicates the existence of ancient enclosures and, therefore, an individual management of this space. In the Gibéu braña, the old corros (circular stone constructions, of small dimensions, with false vault and covered with grass plugs), are still completely abandoned and practically demolished.

Figure 9. Scheme of the elements that make up the landscape of the Saliencia Valley shady slope. Source: Google Earth images (2017). Own elaboration. 


High siliceous platform dissected by stream adjustment, which has modelled shallow and open transverse valleys
adopting the form of a funncl towards its culminating part (riegas).

In the intermediate spaces, which correspond to landings with more or less surface, grazing areas, linked to equinoctial brañas as the one of Las Morteras (right) alternate with shrub formations (piornales). In that shrub formations clearing jobs are visible. This practice is carried out to keep clean the pasture surfaces.

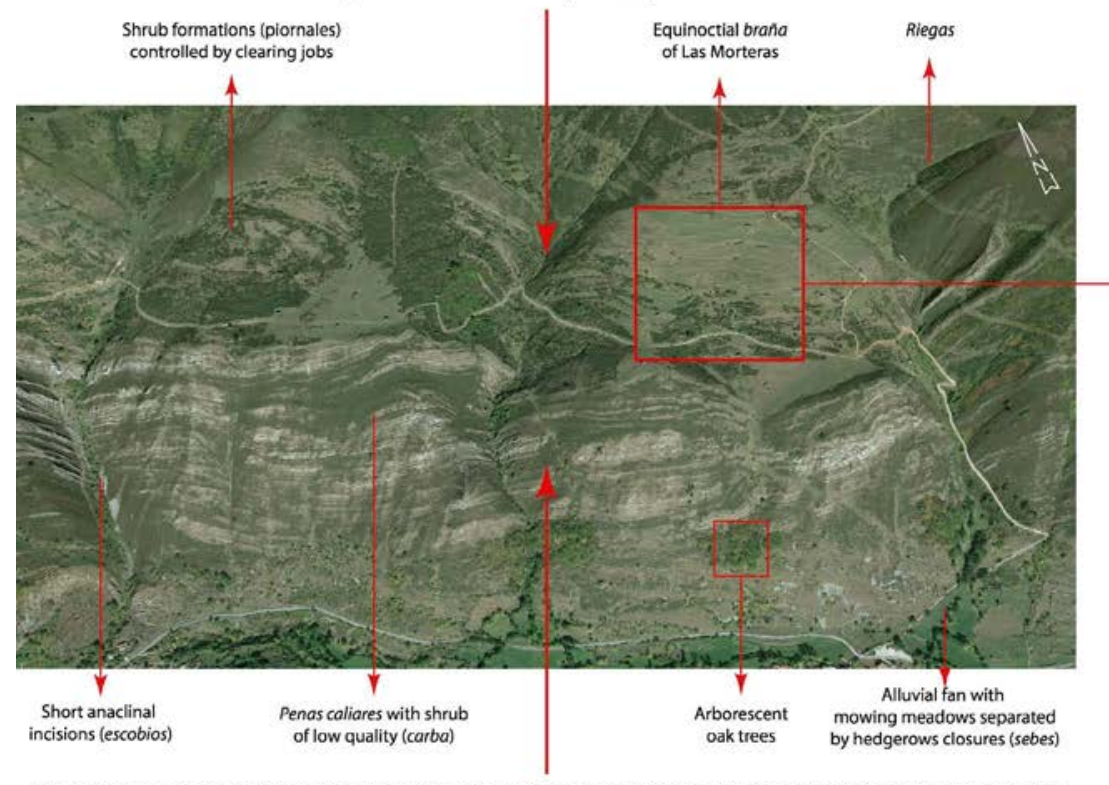

The sunny slope of La Mesa ridge presents a relatively uniform aspect. It is easy to reconstruct the rocky outcrop layout, especially in its culminating part, which is formed ny the resistant Santa Lucia limestones.

The continuity of the rocky outcrops is only interrupted by the occasional presence of short anaclinal incisions (escobios), which, when the aforementioned limestones materiales are reached, have resulted in small and deep incisions. At the foot of this transversal incisions, alluvial fans are formed, covered by meadows which are enclosured by hedgerows (sebes)

On the calcareous surface, with a steep slope (penas caliares) a pasture of regular quality is developed (the term of carba refers to a communal pasture where shrubland abound: gorse, heather, fern and oak scrub). Towards the lower part of the slope, where the limestone is replaced by the slate materials of the Huergas formation, the vegetal covering seems more dense, observing the presence of small patches of arborescent oak trees in progressive dynamics.

ESCOBIOS, PENAS CALIARESY CARBAS OF SUNNY SOPE OF LA MESA RIDGE

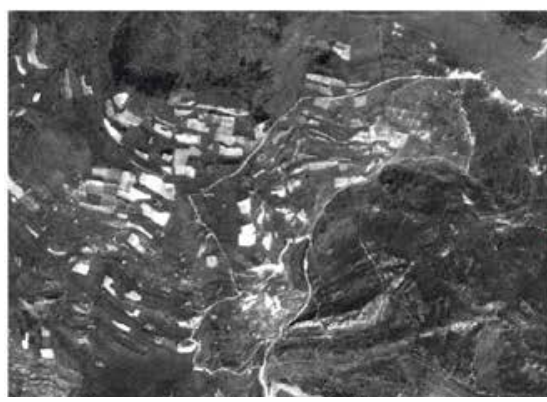

Equinoctial braña of Las Morteras of Saliencia, located at 1,450 meters of altitude. The ecological conditions determined by its position on the sunny slope allowed, despite its high altitude, that in the past, in addition to the use of pastures during the intermediate seasons, that different crops were planted in the plots that appear in whitish tones (wheat, rye, barley, lentils, and there would even be some orchards with vegetables).

- The place-name of mortera, very common in the Asturian mountain, refers precisely to cultivated areas near the settlements of population. They also had a forage use. These were basically collective spaces. Rodriguez Gutierrez (1989) indicates that they could also be called guardas, although the latter seems to be a more generic term.

Figure 10. Scheme of the elements that make up the landscape of the Saliencia Valley sunny slope. Source: Google Earth image, 2017 (upper) and fragment of Series B flight, frame 43615, taken on May 21, 1957. Own elaboration. 
ELEMENTS OF THE TRADITIONAL AGRARIAN LANDSCAPE
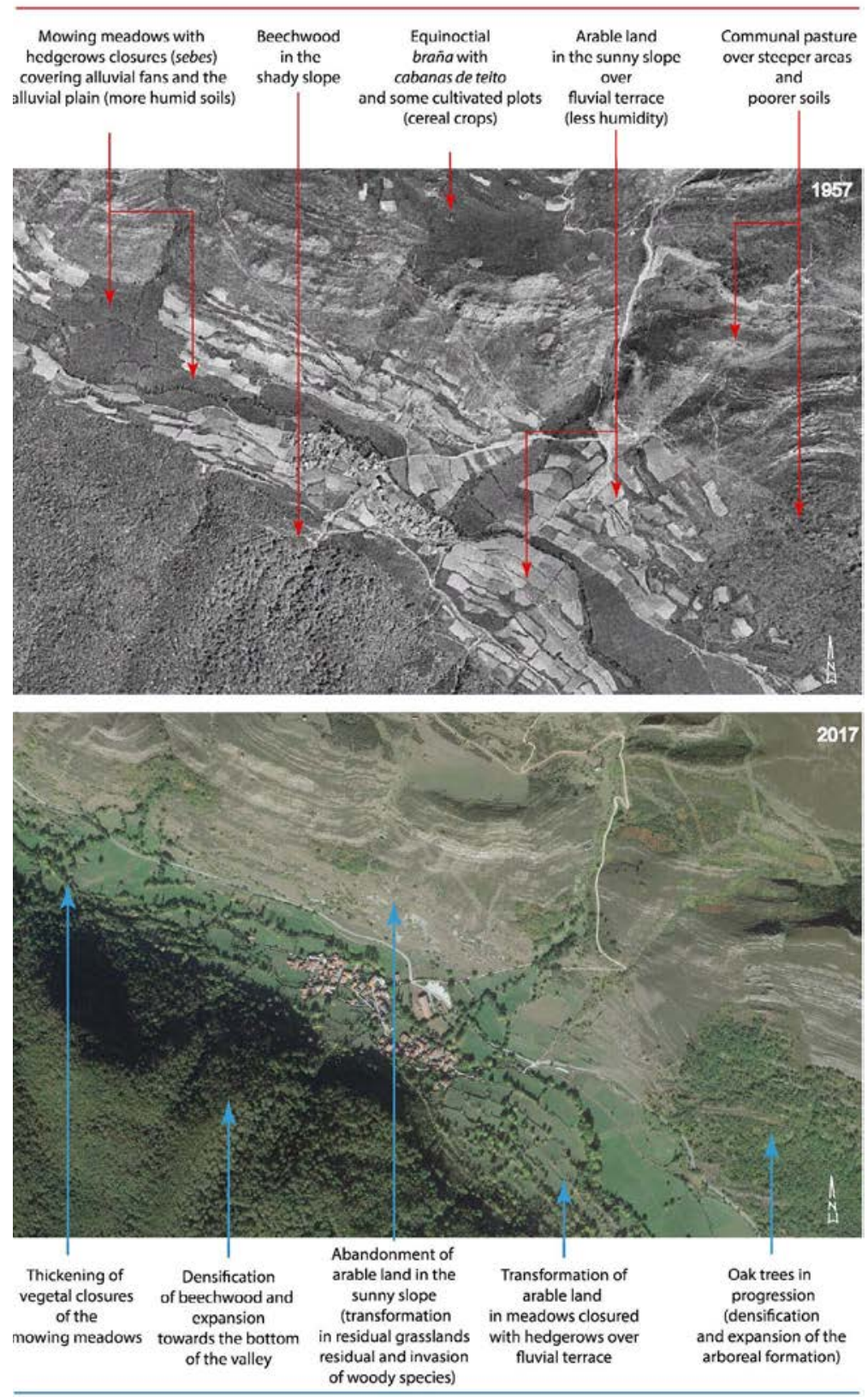

LANDSCAPE DYNAMICS IN THE VILLAGE OF SALIENCIA

Figure 11. Village of Saliencia, analysis on the dynamics of the traditional agrarian landscape. Source: fragment of Series B flight, frame 43616, taken on May 21, 1957 (above); Google Earth image, 2017 (bottom). Own elaboration. 


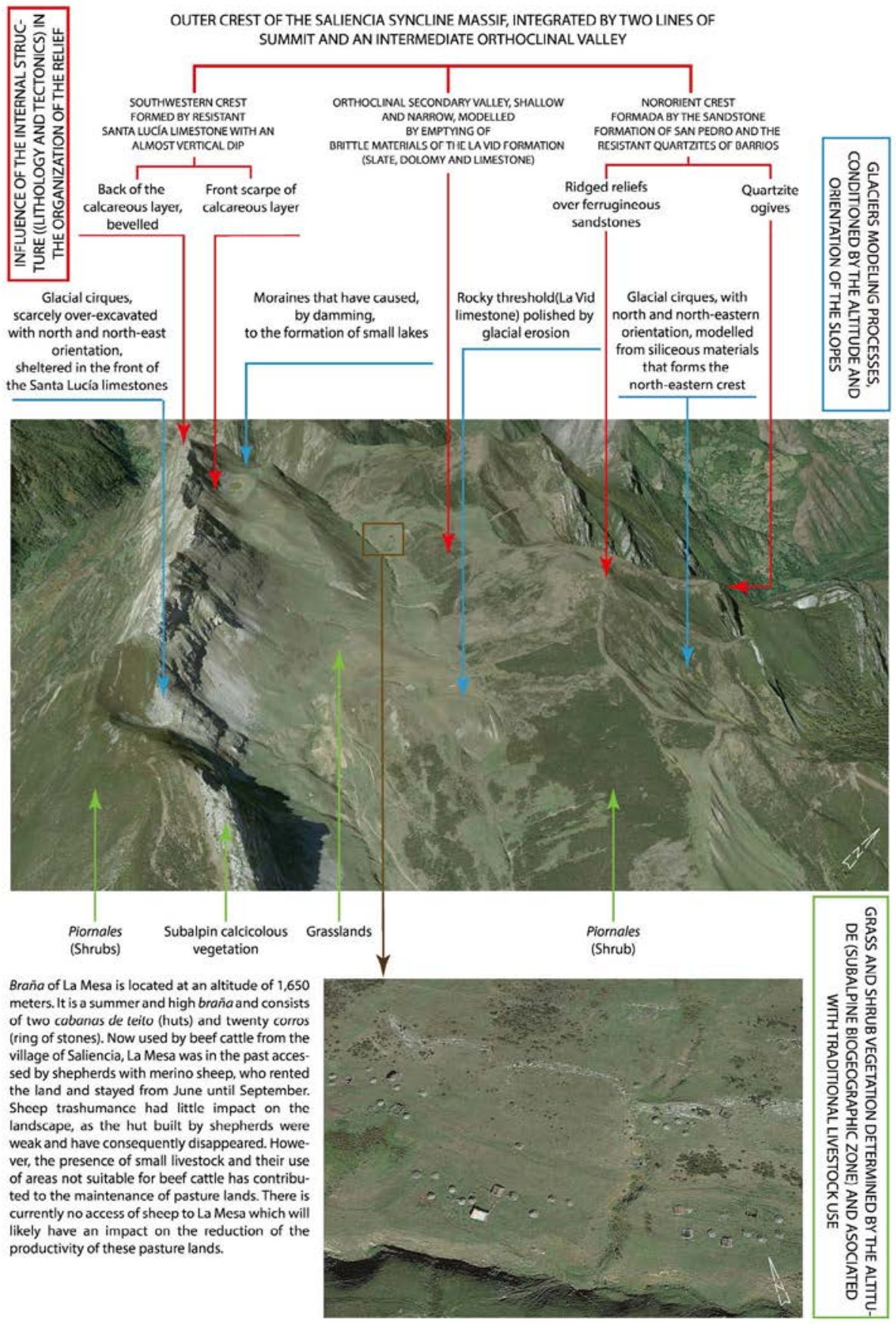

Figure 12. Braña of La Mesa, example of summer braña linked to Mesta. Source: Google Earth image (2017). Own elaboration. 


\section{Discussion}

\subsection{Criteria for the assessment of Outstanding Universal Value}

The UNESCO Committee considers a property as having Outstanding Universal Value if the area meets one or more of the criteria (Table 1). The results shown in the present study reinforce the brief and mainly descriptive content of a first candidacy dossier issued jointly with the Ancares region in April 2007 (ref 5132) and supported by criteria $\mathrm{v}$, vii, ix and $\mathrm{x}$ (whose justification was not attached) (UNESCO, 2018b). In this work, compliance with more criteria (iii, iv, v, vii, viii and $\mathrm{x}$ ) is justified, being the key the significant proportion of indicators evidenced (Table 3). The criteria checked are similar in number and type to those verified in Laponian Area (iii, v, vii, viii, ix), St. Kilda (iii, v, vii, ix, $\mathrm{x}$ ) and Pyrénées-Mont Perdu (iii, iv, v, vii, viii). In Somiedo, it would be:

-iii: the complex livestock exploitation linked to a unique culture, the vaqueiros de alzada, among other kinds of livestock communities.

-iv: the conservation of brañas with corros and teito huts. The teitos, or cabins with vegetal cover (type of construction widely extended in the Cantabrian mountain range) have disappeared in many places, being Somiedo one of the few with sets of high ethnographic and landscape interest.

-v: the representative example of transhumance settlements in the Cantabrian mountains, being the scene of a centennial way of life that managed to adapt to the limitations imposed by the environment and helping to model an integrated landscape in which different elements can still be recognized thanks to the maintenance of a quality beef cattle farm (adapted to the demands of modern market without giving up its traditional know-how).

-vii: the awesome nature of high mountain areas where fluvial, karst, glacial and periglacial modeling have contributed to create a varied landscape of great scenic appeal, in which numerous lakes and lagoons stand out as unique elements: lakes of Saliencia (La Cueva, Calabazosa and Cerveriz) at $1600 \mathrm{~m}$ a.s.1., and Lago del Valle, located at $1580 \mathrm{~m}$ a.s.l. at the feet of the Albos peaks and La Mortera (very popular with hikers and tourists).

-viii: the abrupt and contrasted relief in which the lithological heterogeneity and a long geological evolution have given rise to the conformation of a clear example of Appalachian morphology: alternation of quartzitic and calcareous rocky outcrops and wide slatey inlets (it is recognized as the Cantabrian mountain area where this type is better identified).

-x: the conservation of natural ecosystems in a significant part of the territory, the forests covering almost a quarter of Somiedo. The most important are beech and oak forests, although birch trees also appear in the higher altitude areas and, in the calcareous escarpments of valley bottom, there are holm oaks. The presence of a great variety of animal species should be mentioned, the most emblematic being the capercaillie and the brown Cantabrian bear (both species in danger of extinction). 
Table 3. Indicators that prove Somiedo's compliance with criteria (Som) versus Laponian Area (Lap), St. Kilda (StK) and Pyrénées-Mont Perdu (Pyr).

\begin{tabular}{|c|c|c|c|c|c|c|c|}
\hline $\begin{array}{c}\text { criterial } \\
\text { indicators }\end{array}$ & $\dddot{i i i}$ & $i v$ & $v$ & $v i i$ & viii & $i x$ & $x$ \\
\hline $\begin{array}{l}\text { magnitude and/or intensity of } \\
\text { components and phenomena }\end{array}$ & $\begin{array}{l}\text { Som } \\
\text { Lap } \\
\text { StK }\end{array}$ & $\begin{array}{l}\text { Som } \\
\text { Pyr }\end{array}$ & $\begin{array}{l}\text { Som } \\
\text { Lap } \\
\text { StK } \\
\text { Pyr }\end{array}$ & $\begin{array}{l}\text { Som } \\
\text { Lap } \\
\text { StK } \\
\text { Pyr }\end{array}$ & $\begin{array}{l}\text { Som } \\
\text { Lap } \\
\text { Pyr }\end{array}$ & $\begin{array}{l}\text { Lap } \\
\text { StK }\end{array}$ & $S t K$ \\
\hline diversity & & $\begin{array}{l}\text { Som } \\
\text { Pyr }\end{array}$ & $\begin{array}{l}\text { Som } \\
\text { Lap } \\
\text { StK } \\
\text { Pyr }\end{array}$ & $\begin{array}{l}\text { Som } \\
\text { Lap } \\
\text { StK } \\
\text { Pyr }\end{array}$ & $\begin{array}{l}\text { Som } \\
\text { Lap } \\
\text { Pyr }\end{array}$ & $\begin{array}{l}\text { Lap } \\
\text { StK }\end{array}$ & $\begin{array}{c}\text { Som } \\
\text { StK }\end{array}$ \\
\hline representativeness & $\begin{array}{l}\text { Som } \\
\text { Lap } \\
\text { StK } \\
\text { Pyr }\end{array}$ & $\begin{array}{l}\text { Som } \\
\text { Pyr }\end{array}$ & $\begin{array}{l}\text { Som } \\
\text { Lap } \\
\text { StK } \\
\text { Pyr }\end{array}$ & $\begin{array}{l}\text { Som } \\
\text { Lap } \\
\text { StK }\end{array}$ & $\begin{array}{l}\text { Som } \\
\text { Lap } \\
\text { Pyr }\end{array}$ & $\begin{array}{l}\text { Lap } \\
\text { StK }\end{array}$ & $\begin{array}{c}\text { Som } \\
\text { StK }\end{array}$ \\
\hline rarity and/or residuality & $\begin{array}{l}\text { Som } \\
\text { Lap } \\
\text { StK } \\
\text { Pyr }\end{array}$ & $\begin{array}{l}\text { Som } \\
\text { Pyr }\end{array}$ & $\begin{array}{l}\text { Som } \\
\text { Lap } \\
\text { StK } \\
\text { Pyr }\end{array}$ & & & $\begin{array}{l}\text { Lap } \\
\text { StK }\end{array}$ & $\begin{array}{c}\text { Som } \\
\text { StK }\end{array}$ \\
\hline $\begin{array}{l}\text { aesthetic and scenic quality: } \\
\text { chromaticism, textures, vol- } \\
\text { umes, visual angles ... }\end{array}$ & $\begin{array}{l}\text { Som } \\
\text { Lap } \\
\text { StK }\end{array}$ & $\begin{array}{l}\text { Som } \\
\text { Pyr }\end{array}$ & $\begin{array}{l}\text { Som } \\
\text { Lap } \\
\text { StK } \\
\text { Pyr }\end{array}$ & $\begin{array}{l}\text { Som } \\
\text { Lap } \\
\text { StK } \\
\text { Pyr }\end{array}$ & $\begin{array}{l}\text { Som } \\
\text { Lap } \\
\text { Pyr }\end{array}$ & $\begin{array}{l}\text { Lap } \\
\text { StK }\end{array}$ & $\begin{array}{c}\text { Som } \\
\text { StK }\end{array}$ \\
\hline $\begin{array}{c}\text { adaptation of communities to } \\
\text { the environment and sustain- } \\
\text { able use }\end{array}$ & $\begin{array}{l}\text { Som } \\
\text { Lap } \\
\text { StK } \\
\text { Pyr }\end{array}$ & $\begin{array}{l}\text { Som } \\
\text { Pyr }\end{array}$ & $\begin{array}{l}\text { Som } \\
\text { Lap } \\
\text { StK } \\
\text { Pyr }\end{array}$ & & & & \\
\hline $\begin{array}{l}\text { effective maintenance of an- } \\
\text { cestral activity: knowledges, } \\
\text { traditions, language, spirit } \\
\text { and feeling, techniques and } \\
\text { management systems }\end{array}$ & $\begin{array}{l}\text { Som } \\
\text { Lap } \\
\text { Pyr }\end{array}$ & $\begin{array}{l}\text { Som } \\
\text { Pyr }\end{array}$ & $\begin{array}{l}\text { Som } \\
\text { Lap } \\
\text { Pyr }\end{array}$ & & & & \\
\hline $\begin{array}{l}\text { conservation without major } \\
\text { alterations: components, ma- } \\
\text { terials, forms, locations, uses, } \\
\text { phenomena, linked processes }\end{array}$ & $\begin{array}{l}\text { Som } \\
\text { Lap } \\
\text { Pyr }\end{array}$ & $\begin{array}{l}\text { Som } \\
\text { Pyr }\end{array}$ & $\begin{array}{l}\text { Som } \\
\text { Lap } \\
\text { Pyr }\end{array}$ & $\begin{array}{l}\text { Som } \\
\text { Lap } \\
\text { StK }\end{array}$ & $\begin{array}{l}\text { Som } \\
\text { Lap }\end{array}$ & $\begin{array}{l}\text { Lap } \\
\text { StK }\end{array}$ & $\begin{array}{c}\text { Som } \\
\text { StK }\end{array}$ \\
\hline $\begin{array}{c}\text { official protection at different } \\
\text { administrative scales }\end{array}$ & $\begin{array}{l}\text { Som } \\
\text { Lap } \\
\text { StK } \\
\text { Pyr }\end{array}$ & $\begin{array}{l}\text { Som } \\
\text { Pyr }\end{array}$ & $\begin{array}{l}\text { Som } \\
\text { Lap } \\
\text { StK } \\
\text { Pyr }\end{array}$ & $\begin{array}{l}\text { Som } \\
\text { Lap } \\
\text { StK } \\
\text { Pyr }\end{array}$ & $\begin{array}{l}\text { Som } \\
\text { Lap } \\
\text { StK } \\
\text { Pyr }\end{array}$ & $\begin{array}{l}\text { Lap } \\
\text { StK }\end{array}$ & $\begin{array}{c}\text { Som } \\
\text { StK }\end{array}$ \\
\hline $\begin{array}{l}\text { involvement of scientific, in- } \\
\text { stitutional and social agents }\end{array}$ & $\begin{array}{l}\text { Som } \\
\text { Lap } \\
\text { StK } \\
\text { Pyr }\end{array}$ & $\begin{array}{l}\text { Som } \\
\text { Pyr }\end{array}$ & $\begin{array}{l}\text { Som } \\
\text { Lap } \\
\text { StK } \\
\text { Pyr }\end{array}$ & $\begin{array}{l}\text { Som } \\
\text { Lap } \\
\text { StK } \\
\text { Pyr }\end{array}$ & $\begin{array}{l}\text { Som } \\
\text { Lap } \\
\text { Pyr }\end{array}$ & $\begin{array}{l}\text { Lap } \\
\text { StK }\end{array}$ & $\begin{array}{c}\text { Som } \\
\text { StK }\end{array}$ \\
\hline
\end{tabular}

Source: Own elaboration supported by reference studies about Somiedo (see chapter 8) and UNESCO dossiers (2018b). 
The representativeness and vigor of its geomorphological and biogeographic features, within the context of the Cantabrian mountain range and the Atlantic European mountain, together with the exceptionality of its cultural component, converging singular forms of exploitation and traditional livestock settlement (from various types of transhumance with different geographic scope and both material and immaterial footprint), justify its consideration as a zone to be included in the World Heritage List. Furthermore, there are not many mixed-type properties on the World Heritage List (38 in the world, 7 in Europe) or in its type (mountain with natural and cultural material and intangible components): 6 in Europe (just 2 in the Atlantic facade and one in southwestern Europe).

\subsection{Authenticity}

As an area with elements to meet any of the first four criteria, Somiedo must contain conditions of so-called authenticity. And for this, rigor and credibility of the information sources are essential, as well as dissemination and transcendence. In this case, multiple cultural manifestations and research projects build the artistic, historic, social, and scientific dimensions of heritage. They are, above all, research studies validated by the scientific community itself and characterized by respect for a documentary and bibliographic genealogy that is essential to build new contributions. Authors are not only local but also from other regions and countries (HernándezPacheco, Krüger, Muñoz...).

Being the scientific context similar to that of the Pyrenees, projects subsidized by public funds to deepen cultural features knowledge have been relatively frequent, including inventories of buildings and other material remains (as for the mallatas -traditional shepherd huts-in Aragon) (Fillat et al., 2005). These studies demonstrate the existence of relevant qualities in all the variety of features contemplated by UNESCO: form and design; materials and substance; use and function; traditions, techniques and management systems; location and setting; language, and other forms of intangible heritage; spirit and feeling; and other internal and external factors.

In relation to authenticity, there have been no reconstructions of the material heritage but only conservation tasks (with the exception of just six cabanas recreated in the Lagos de Somiedo campsite). The survival of livestock activities in accord with the traditional life, like the Pyrenean pastoralism (Laborda et al., 2017), contributes to the visual and material authenticity on the basis of indigenous resources. Coordination by Adolfo García favored a respectful intervention (García, 2011). This challenge is accomplished on the basis of a minimum intervention, as it is in St. Kilda too (UNESCO, 2018b).

In this section it is also worth mentioning the use of motorized transport by shepherds (including vaqueiros, as in Lapland with the Saami). It can be understood as the application of technological developments for a traditional purpose. But it presents a potentially harmful impact that must be addressed through management actions (UNESCO, 2018b). 


\subsection{Integrity}

Satisfying conditions of integrity has to do with the wholeness and intactness of the natural and cultural heritage. The extent to which the property includes all the necessary elements to express its Outstanding Universal Value must be assessed (UNESCO, 2018a). In the case of Somiedo, already individually and above, as a whole, the variety of indicators that are met for each criterion come to corroborate the presence of Outstanding Universal Value. And regarding the necessary proof that the area has adequate size to ensure the complete representation of the characteristics that convey the property's significance, it must be said that outstanding features define already the extension of the Biosphere Reserve and the Natural Park.

Refering to adverse effects of development or neglect, there are no major conditions related to the pressure of non-traditional uses thanks to the effective application of the management plan, endowed with adequate restrictions (Gobierno del Principado de Asturias, 2015). The main risk would be more related to the decline of livestock activity.

Bio-physical processes and landforms are relatively intact. The area contains enough habitats free of major risks for maintaining the most diverse fauna and flora characteristic of the bio-geographic region and ecosystems under consideration. Vegetation is in progressive dynamics in the greater biogeographic areas. For example, there are beech forests in expansion thanks to the Natural Park planning (Díaz and Fernández, 1998; López and Ramos, 2007; Rodríguez, 2015).

As required by UNESCO, the physical fabric of the elements considered in the property and its significant features are mostly in good condition, and the impact of deterioration processes controlled. It can be said that relationships and dynamic functions essential to their distinctive character are stronger than in other cantabrian mountain areas (Gobierno del Principado de Asturias, 2017).

Human activities are mainly consistent with the Outstanding Universal Value, ecologically and culturally sustainable, as well as beneficial for quality of life (Parque Natural de Somiedo, s.f.). Livestock activity can be guarantor of landscape maintenance and its diversity as in Laponian Area and Pyrénées-Mont Perdu (Dahlström, 2003; Rössler, 2010; García Ruiz and Lasanta, 2018). The fact of obtaining the Q quality label of Protected Natural Areas and being rewarded by European Charter for Sustainable Tourism proves it too. In any case, the conditions of integrity reach all areas, being Pola de Somiedo the only place where urban development is something larger, but very content. There are not many dissonant actions.

Although not very accessible from the main markets, Somiedo is not a place with such a remote character or with a fossilized cultural landscape (like St. Kilda), which accentuates the merit of conserving environments and ways of life since human occupation continues and regulates external influences. In conclusion, Somiedo is very representative of a natural and geocultural region and has the capacity to illustrate and mantain its essential and distinctive elements (Gobierno del Principado de Asturias, 2018a, 2018b; UNESCO, 2018b). 


\subsection{Protection and management}

Somiedo does have long-term legislative, regulatory, institutional and traditional protection and management to ensure that Outstanding Universal Value, including the conditions of integrity and authenticity, can be held over time. The area has already been recognized under six different forms of protection convering both natural and cultural values (Biosphere Reserve, SPA, SCI, Point Geological Interest, Natural Park, Natural Monument...), which are adapted to the current legislation in the corresponding scales (there are also several national and international designations in Laponian Area, St. Kilda and Pyrénées-Mont Perdu). These protection figures have adequately delineated boundaries that correspond to the geographical distribution of the attributes worthy of institutional attention: the adequate boundaries for re-launching the candidacy (UNESCO, 2018a, 2018b).

Given that compliance with any of the criteria between i-vi is contemplated, areas that may contain potential virtues to reinforce the World Heritage designation in the future should be included. In that sense, a possible integration of nearby lands with similar ethnographic character and some shared natural features could be proposed (Krüger, 1948; Rodríguez, 2015; Rodríguez and Sevilla, 2017): some areas that are today in the Las Ubiñas-La Mesa Biosphere Reserve and Natural Park (to the east) or in the Fuentes del Narcea, Degaña and Ibias Natural Park-Muniellos Biosphere Reserve (to the west). It would also be possible to expand the World Heritage area to the South (Babia and Laciana Valley Biosphere Reserves), although management would be more difficult because they are located in a different administrative region (Castile and León). In addition, considering compliance with criteria vii-x, the areas involved in the conservation of species, habitats, processes and protected natural phenomena are in fact included within the boundaries.

With regard to the need to establish a buffer zone (required by UNESCO), it should be noted that the current management plan already establishes a zoning with different intensities. There is a gradation in land uses that serves as a buffer (Gobierno del Principado de Asturias, 2015).

Finally, there is an active participation of local agents in the care of the area. The activities developed by Fundación Oso Pardo as well as the local efforts recognized with the Exemplary Town Prize are examples. Local agents and population protect nature and cultural tradition as they do in other sites (Saami communities are involved in Laponian Area development actions and planning) (UNESCO, 2018b), being certainly complex in the case of Somiedo because of the fragmentation of resources ownership. They respect the protected area management plan and enrich institutional actions within the framework of the Local Action Group for the Development of Royal Way of La Mesa. As in the example of Pyrenees, the support coming from regional and state aid to sustainable development projects conducted by local groups and family enterprises constitutes an essential complement.

\section{Conclusions}

The research has been carried out in a contemporary context of valorisation of mountain spaces that is based on the institutional recognition of material and immaterial 
heritage values. And it took into account the fact that this same perspective, integrated into the role of institutional, economic and social agents, stands as a way to face challenges linked to the demographic revitalization and the economic and sociocultural development of rural mountain communities in the context of globalization. This starting point has proved adequate to give meaning to the opportunity to relaunch Somiedo's candidacy.

Indeed, the research pursued an integrated knowledge of Somiedo to determine the qualities and differential values that can guide heritage actions. Mechanisms are needed to articulate the assessment according to principles, criteria and actions ordered, not random and scientifically based. So when designing work procedure for this purpose, we had to face a sequence of decision-making to achieve rationality at work and to not distort the result.

The choice of municipal scale seemed appropriate for administrative management, taking also into account that it fences the extension of territorial processes that originate exceptional features; but it added a difficulty, that of covering a sizeable area. Hence the decision to reach a greater degree of detail deepening into a smaller key area that concentrates all the qualities: Saliencia Valley.

Defining the type of landscape has not caused difficulties since the projects in which this study is included continue a line of work whose first results, years ago, found the classification, definition and characterization of Spanish landscapes. This fact has contributed to enhance the rigor and rationality as it helped to identify other UNESCO reference properties for comparison and to establish appropriate criteria and indicators for the assessment.

Regarding the criteria, UNESCO does offer qualitative statements sufficiently precise and correctly conceived from the point of view of casuistry, so that its selection has not generated any doubts. This has not been the case, however, with the selection of indicators because there is no consensus regarding them; a problem solved by two ways: on the one hand, the orientation of UNESCO dossiers for other territories with similar characteristics; on the other hand, the research team experience in previous studies on mountain heritage landscapes and their territorial values, for which a theoretical basis had been established. This combination has finally been coherent since the approach of UNESCO distinctions regarding mixed natural-cultural properties is rooted in the same widespread tradition of intellectual and institutional valorization of territory and landscape.

The need to rationalize and systematize the study of a complex physical and anthropic environment with the specific objective of distinguishing territorial qualities, and of assessing them according to a system of criteria and indicators, required also a special bibliographic effort (given the profusion of scientific contributions about the area). And the task has proved as arduous as it is profitable because the variety of branches of knowledge corresponds to the diversity of territorial attributes found in Somiedo. Otherwise, the vivid landscape imprint of these attributes, clearly identifiable, well preserved and abundant, came to facilitate field work; being this same imprint the 
one that reinforces the expressiveness of the graphic materials that have been elaborated to contribute to landscape interpretation. The suitability of implementing the landscape dimension in research concerning UNESCO World Heritage mixed properties seems proven due to that strong visual imprint of natural and cultural material and immaterial components.

The research on Somiedo seems opportune, in short, for evidencing the conjunction of values that meet conditions leading to emerge in a sort of universal hierarchy. The results can be used to demonstrate the potential of Somiedo and guide the argument before an eventual re-launch of the candidacy. The present investigation would then be framed within a knowledge transfer process that requires a subsequent contact with the territorial agents. At that moment, this study would also constitute a supporting text for supplementary work: the formulation of an updated management model. It could even be useful for candidacies of other mountain areas in relational landscape categories.

But it must also result in dissemination to the general public, particularly among the local population whose identity and civic values are being enriched. Also, given that a living and functional landscape is analized, World Heritage designation can be undestood as a factor that guides territorial development. In a context of search for viability of the rural activity, UNESCO determinations could contribute to local and regional competitiveness, generating quality image for products associated with high value landscapes. In the imperative attempt to guarantee a heritage legacy, durable economic use of territory should not be lost since the economic activities themselves set the population and partly convey heritage values, identity and sense of belonging. Hence the need for management that combines sustainable exploitation of resources with protection and conservation.

In this sense, with the endorsement of official bodies involved in the management of Somiedo, we have started a complementary line of work to integrate technological innovation in the valorisation of the Royal Way of La Mesa: it is about the design of an Augmented Reality tool that promotes educational activities and tourist practices wich are coherent with the maximum heritage protection at universal scale.

\section{Acknowledgements}

Carmen Rodríguez, Juan Sevilla and Ícaro Obeso wish to thank the Spanish Programa Estatal de Fomento de la Investigación Científica y Técnica de Excelencia (call 2015, Ministerio de Economía y Competitividad), Programa Estatal de Investigación, Desarrollo e Innovación Orientada a los Retos de la Sociedad (call 2017, Ministerio de Economía y Competitividad) and FEDER program (European Union) for their support. This research work has been developed within the framework of two projects: Paisajes culturales de la Lista Patrimonio Mundial. Claves para la identificación y criterios para la gestión de paisajes agroganaderos, mineros e industriales en la España Atlántica (Principal Researcher: María Cruz Porcal, reference code CSO2015-65787-C6-3-P) and La realidad aumentada como herramienta para la explicacion del paisaje. Aplicaciones a la docencia y al turismo (Principal Researcher: Felipe Fernández, reference code CSO2017-84623-R). We would also like to thank José Alba (Department of Applied 
Economics in the University of Oviedo) for his interest in our work and the conversations held during the research period.

\section{References}

Alba, J. 1999. Potencialidad de los espacios naturales protegidos como impulsores del desarrollo socioeconómico de su área de influencia el caso del Parque Natural de Somiedo (Asturias) 1988-98. Tesis doctoral, Universidad Autónoma de Madrid.

Alba, J. 2012. Spain: Somiedo Natural Park bringing “everything to live'. In: N. Dudley, N. and Stolton, S. (Eds.), Protected Landscapes and Wild Biodiversity. Volume 3 in the Values of Protected Landscapes and Seascapes Series, Gland, Switzerland, IUCN, 104, pp. 27-34.

Alba, J., Rivas, D.M. 1996. El turismo en los espacios naturales protegidos: consideraciones generales y análisis del Parque natural de Somiedo (Asturias). In: L. Valdés Peláez, A.V. Ruiz (Coords.), Turismo y promoción de destinos turísticos: implicaciones empresariales. Universidad de Oviedo, pp. 257-274.

Álvarez, M. 2001. El teito de escoba en Somiedo. Colegio Oficial de Aparejadores y Arquitectos Técnicos del Principado de Asturias, Oviedo, 155 pp.

Álvarez, J.M., Fernández, B., Fernández, M., López, M.J. 1990. Espacio y propiedad en un territorio de montaña: la tierra del Privilexu (Teberga). Boletín del Instituto de Estudios Asturianos 133, 145-214.

Aplin, G. 2007. World Heritage Cultural Landscapes. International Journal of Heritage Studies 13 (6), 427-446. https://doi.org/10.1080/13527250701570515.

Ashby, E. 1978. Reconciling man with the environment. Oxford University Press, 104 pp.

Ayuntamiento de Somiedo 2018. Ecomuseo de Somiedo. Available at: https://www.somiedo.es/ ecomuseo-de-somiedo (Last Access: 12/10/2018).

Barron, H.F., Marvinney, R.G., Wylezol, P. 2016. International Appalachian Trail bridges Atlantic divide. Earth Heritage 45, 20-22.

Béghain, P. 1998. Le patrimoine: culture et lien social. Presses de Science Po, Paris, 115 pp.

Berdoulay, V. 1992. Les valeurs géographiques. In: A. Bailly, R. Ferras, D. Pumain (Eds.), Encyclopédie de Géographie. Economica, Paris, pp. 385-403.

Berdoulay, V. 2004. Requalification des lieux et des espaces publics à travers la réinvention des rapports à la nature. Hégoa 24, 9-10.

Besse, J.M. (Ed.) 2009. Le goût du monde. Actes du Sud ENSP/Centre du Paysage, Arles.

Bouisset, C., Degrémont, I. 2010. Patrimoines Naturels. Sud-Ouest Européen. Revue Géographique des Pyrénées et du Sud-Ouest 30, 1-3.

Bouisset, C., Degrémont, I., Sevilla, J. 2010. Le patrimoine naturel aquitain vu du web: discours, valeurs, fonctions. Sud-Ouest Européen. Revue Géographique des Pyrénées et du Sud-Ouest 30, 85-98. https://doi.org/10.4000/soe.1283.

Caso, J.M., Canga, B., Piñán, C. 2011. Jovellanos y la naturaleza. Fundación Foro Jovellanos del Principado de Asturias, Gijón, 250 pp.

Castañón, J.C. 1989. Las formas de relieve de origen glaciar en los sectores central y oriental del Macizo Asturiano. Tesis Doctoral (en microfichas), Universidad de Oviedo.

Cátedra, M. 1989. La vida y el mundo de los vaqueiros de Alzada. Centro de Investigaciones Sociológicas, Madrid, $176 \mathrm{pp}$.

Clark, K., Drury, P. 2002. Du monument au citoyen: les fonctions du patrimoine culturel dans une Europe en évolution. In: Fuctions du patrimoine culturel dans une Europe en changement. Strasbourg. Conséil de l'Europe, pp. 119-124.

Concepción, J., García, A., Mayor, M. 2008. Las brañas asturianas: un estudio etnográfico, etnobotánico y toponímico. RIDEA, Oviedo, $280 \mathrm{pp}$. 
Corbera, M. 2016. El paisaje, su patrimonialización y el beneficio económico. Investigaciones Geográficas 65, 9-24. https://doi.org/10.14198/INGEO2016.65.01.

Council of Europe. 2018. European Landscape Convention. Available at: https://www.coe.int/en/ web/conventions/full-list/-/conventions/treaty/176 (Last access: 14/10/2018).

Čučković, Z. 2016. Advanced viewshed analysis: a Quantum GIS plug-in for the analysis of visual landscapes. The Journal of Open Source Software 1 (4), 32. https://doi.org/10.21105/ joss.00032.

Dahlström Nilsson, Å. 2003. Negotiating Wilderness in a Cultural Landscape: Predators and Saami Reindeer Herding in the Laponian World Heritage Area. Acta Universitatis Upsaliensis, Uppsala, 535 pp.

Díaz, T.E., Fernández, J.A. 1998. El paisaje vegetal. In: El Principado de Asturias. Patrimonio natural. Principado de Asturias, Oviedo, pp. 30-35.

Droste, B. von, Plachter, H., Rössler, M. (Eds.) 1995. Cultural landscapes of universal value. Components of a global strategy. Fischer Verlag, Jena, 464 pp.

Feo, F. 1980. Los vaqueiros de alzada en el occidente asturiano. Estudios Geográficos 160, 303319.

Feo, F. 1985. Transformaciones recientes de la economía de los vaqueiros. Narria 39-40, 13-15.

Fernández, F. 1992. El valle de Pigüeña-Somiedo: concejos de Somiedo y Miranda. In: G. Morales (Dir.), Geografía de Asturias, vol. 3. Editorial Prensa Asturiana, Oviedo, pp. 109-128.

Fernández, G. (Dir.) 2005. Atlas escolar de Asturias. Ediciones Nobel, Oviedo, 176 pp.

Fernández, M. 2003. El Camín Real de la Mesa. Escardar 2, 11-13.

Fernández, M., López, P., González, D. 2013. Prácticas ganaderas en la Cordillera Cantábrica. Aproximación multidisciplinar al estudio de las áreas de pasto en la Edad Media, Debates de Arqueología Medieval 3, 167-219.

Fernández, V., Silva, R. 2015. Paisajes españoles susceptibles de ser incluidos en la Lista de Patrimonio Mundial de Unesco. Criterios para su identificación y selección. Boletín de la Asociación de Geógrafos Españoles 68, 253-278. http://dx.doi.org/10.21138/bage.1861.

Fillat, F., Bueno, C.G., Gartzia, M., Gómez García, D., Aguirre, J. 2005. Inventario de las zonas de pastoreo más frecuentadas en la Montaña de Sesa (Parque Nacional de Ordesa y Monte Perdido, Puértolas) y la influencia del pastoreo en la dinámica de los pastos. In: Producciones agroganaderas: Gestión eficiente y conservación del medio natural, Vol. II., XLV Reunión Científica de la SEEP, pp. 825-831.

Fundación Princesa de Asturias 2018. Villar de Vildas, Somiedo. Available at: http://www.fpa.es/ es/premio-al-pueblo-ejemplar-de-asturias/galardonados/villar-de-vildas-somiedo.html (Last access: 12/10/2018).

García, A. 1988. Los vaqueiros de alzada. Un estudio histórico-antropológico. Consejería de Educación, Cultura y Deportes del Principado de Asturias, Oviedo, 400 pp.

García, A. 1995. La cultura somedana. Una aproximación etnográfica. In: Somiedo, Parque natural. Senda Editorial, Madrid, pp. 5-89.

García, A. 2003. La trashumancia en Asturias. In: L.V. Elías, F. Novoa (Coords.), Un camino de ida y vuelta. La trashumancia en España. Ediciones Lunwerg, Barcelona, pp. 95-109.

García, A. 2009. Los vaqueiros de alzada de Asturias. Un estudio histórico-antropológico. KRK Ediciones, Oviedo, $1064 \mathrm{pp}$.

García, A. 2011. Trashumancia y brañas del parque natural de Somiedo. Gobierno del Principado de Asturias, Oviedo, 45 pp.

García, A.L. 1997. El proceso de desarrollo de los Itinerarios Geográficos. Didáctica Geográfica 2, segunda época, 3-9.

García, J.L., Fernández, C., García, E. 1976. El Camino Real del Puerto La Mesa. Colegio Oficial de Arquitectos de León y Asturias, León. 
García Ruiz, J.M., Lasanta, T. 2018. El Pirineo Aragonés como paisaje cultural. Pirineos 173, e038. https://doi.org/10.3989/pirineos.2018.173005

García, X.L. 2018. Toponimia asturiana. El porqué de los nombres de nuestros pueblos. Buscador de topónimos. Available at: https://mas.Ine.es/toponimia/index.php?leer=154\&palabra=Bra\%F1a (Last access: 19/11/2018).

Gobierno del Principado de Asturias 2015. Decreto 169/2014, de 29 de diciembre, por el que se declara la Zona especial de Conservación Somiedo (eS 0000054) y se aprueba el I Instrumento de Gestión Integrado de diversos espacios protegidos en el Concejo de Somiedo. Boletín Oficial del Principado de Asturias, núm. 3 de 5-I-2015, 1-97.

Gobierno del Principado de Asturias 2017. Plan Demográfico del Principado de Asturias 2017-2027. Available at: http://movil.asturias.es/portal/site/webasturias/menuitem.4b280f8214549ead3e2d6f77f2300030/?vgnextoid=35f68cdc5625f510VgnVCM10000097030a0aRCRD\&i18n.http.lang=es (Last access: 01/12/2018).

Gobierno del Principado de Asturias 2018a. Parque Natural de Somiedo. Available at: https:// www.asturias.es/medioambiente/articulos/ficheros/Parque_Natural_de\%20Somiedo.pdf (Last access: 12/10/2018).

Gobierno del Principado de Asturias 2018b. Reserva de la Biosfera de Somiedo. Available at: https://www.asturias.es/medioambiente/articulos/ficheros/Reserva\%20de\%20la\%20Biosfera\%20de\%20Somiedo.pdf (Last access: 12/10/2018).

Gómez, J. 2013. Del patrimonio paisaje a los paisajes patrimonio. Documents d'Anàlisi Geogràfica 59/1, 5-20. https://doi.org/10.5565/rev/dag.48

González, D. 2011. Vías romanas de montaña entre Asturias y León: La integración de la "Asturia transmontana" en la red viaria de Hispania, Zephyrus: Revista de prehistoria y arqueología 67, 171-192.

Graña, A., López, J. 2007. Los teitos en Asturias, Un estudio sobre la arquitectura con cubierta vegetal. Red de Museos Etnográficos de Asturias, Gijón, 232 pp.

Guillaume, M. 1990. Invention et stratégies du patrimoine. In: H.P. Jeudy (Dir.), Patrimoines en folie. Ministère de la Culture et de la Communication, Édition de la Maison des Sciences de l'Homme, Paris, pp. 12-20.

Hernández-Pacheco, F. 1929. Datos sobre geología asturiana (Leitariegos y Somiedo). Boletín de la Real Sociedad Española de Historia Natural tomo XXIX, 295-296.

Hernández-Pacheco, F. 1930. Por los puertos de la cordillera cantábrico-astúrica: de Leitariegos a Somiedo y los lagos. Peñalara Revista Ilustrada de Alpinism, 172-181.

Krüger, F. 1948. Las brañas. Contribución a la historia de las construcciones circulares en la zona astur-galaico-portuguesa. Boletín del Instituto de Estudios Asturianos 8, 41-98.

Laborda, R., Villalba-Mouco, V., Lanau, P., Gisbert, M., Sebastián, M., Domingo, R., Montes, L. 2017. El Puerto Bajo de Góriz (Parque Nacional de Ordesa y Monte Perdido). Ocupación y explotación de un paisaje de alta montaña desde la prehistoria hasta el siglo XX. Bolskan 26, 9-30.

Lasanta, T. 2010. Pastoreo en áreas de montaña: estrategias e impactos en el territorio. Estudios Geográficos 268, 213-233. https://doi.org/10.3989/estgeogr.0459.

Linares, F. 2004. La arquitectura de las brañas somedanas. Universidad de Valladolid, Valladolid. López, A., Ramos, J.E. 2007. El mensaje del valle secreto. Valle de Saliencia. Parque Natural de Somiedo y Reserva de la Biosfera. Principado de Asturias, Obra Social La Caixa, Oviedo, $139 \mathrm{pp}$.

Luengo, A., Rössler, M. (Eds.) 2012. Paisajes culturales del Patrimonio Mundial. Ayuntamiento de Elche, Elche, 362 pp.

Maderuelo, J. (Ed.) 2007. Paisaje y Arte. Abada Editores, Huesca, 270 pp. 
Madrazo, S. 1977. Las transformaciones en la red viaria asturiana 1750-1868. Boletín del Instituto de Estudios Asturianos 90-91, 61-138.

Mañana, G. 2011. El Camín real de La Mesa. Cajastur, Oviedo, 3 vols.

Martínez, L.M. 2006. Por las brañas de Somiedo. Ediciones Azucel, Aviles, 236 pp.

Martínez de Pisón, E. 1997. El paisaje, patrimonio cultural. Revista de Occidente 104-105, 169189.

Martínez de Pisón, E. 2004. 200 años de pirineísmo. In: E. Anía, M. García, A. Tornos, E. Viñuales (Dirs.), Parques Nacionales de Montaña. Organismo Autónomo de Parques Nacionales, Madrid, pp. 59-65.

Mata, R. (Coord.) 2015. Paisajes culturales de la lista de patrimonio mundial. claves para su identificación y criterios para su gestión. Documento de trabajo, Dirección General de Investigación Científica y Técnica.

Mata, R., Meer, A., Puente, L. 2012. Sustainable development and maiking of territory and everyday landscapes as heritage-an experience in the Cantabrian Mountains. In: J.M. Feria (Ed.), Territorial Heritage and Development. Taylor and Francis, pp. 141-159.

Menéndez, R.A. 1994. Geomorfología del área de Somiedo (Cordillera Cantábrica; Norte de España). Aplicaciones de los Sistemas de Información Geográfica al estudio del relieve. Tesis Doctoral (inédita), Universidad de Oviedo.

Menéndez, R.A., Marquínez, J. 1996. Glaciarismo y evolución tardiglaciar de las vertientes en el valle de Somiedo. Cordillera Cantábrica. Cuaternario y Geomorfología 10 (3-4), 21-31.

Molinero, F., Ojeda, J.F., Tort, J. (Coords.) 2011. Los paisajes agrarios en España: caracterización, evolución y tipificación. Ministerio de Medio Ambiente y Medio Rural y Marino, Madrid, $606 \mathrm{pp}$.

Molinero, F., Tort, J., Ojeda, J.F., Ruiz, E., Martínez, E., Silva, R., Mata, R. (Coords.) 2013. Atlas de los paisajes agrarios de España. Ministerio de Agricultura, Alimentación y Medio Ambiente, Madrid, 504 pp. (vol. 1) and 574 pp. (vol. 2).

Muñoz, J. 1977. Morfología estructural y glaciarismo en la Cordillera Cantábrica, el relieve del sinclinal de Saliencia (Asturias-León). In: V Coloquio de Geografía. A.G.E., Universidad de Granada, Granada, pp. 57-65.

Muñoz, J. 1980. Morfología estructural y glaciarismo en la Cordillera Cantábrica: el relieve del sinclinal de Saliencia (Asturias-León), Ería. Revista de Geografía 1, 35-65.

Muñoz, J. 1986. Formas de relieve glaciar: el macizo sinclinal de Saliencia (Cordillera Cantábrica). In: Atlas de Geomorfología. Alianza Editorial, Madrid, pp. 209-228.

Nogué, J. 2010. El retorno del paisaje. Enrahonar. Quaderns de Filosofia 45, 123-136.

Ortega, N. 1986. La Institución Libre de Enseñanza y el entendimiento del paisaje madrileño. Anales de Geografía de la Universidad Complutense 6, 81-98.

Ortega, N. 2010. El lugar del paisaje en la geografía moderna. Estudios Geográficos 269, 367-393. https://doi.org/10.3989/estgeogr.201012.

Parque Natural de Somiedo. s.f. Posibilidades para el aprovechamiento sostenible de los recursos naturales en el Parque Natural de Somiedo. Ministerio de Agricultura, Alimentación y Medio Ambiente, Fundación Biodiversidad, 117 pp.

Peyroux, C. 1992. La calzada romana de La Mesa - El Camín Real. Guía turística y Cultural. Principado de Asturias, Oviedo, $57 \mathrm{pp}$.

Pisa, P. 2015. Red viaria en Asturias: De las vías romanas del oro a los caminos medievales. Tesis Doctoral, Universidad de Oviedo. Available at: http://hdl.handle.net/10651/36668 (Last access: $12 / 10 / 2018)$.

Porcal, M.C. 2014. Heritage landscapes, tourism and sustainable development. Heritage value and touristic explotation of vineyard cultural landscapes in the Basque Country (Spain). 
In: HERITAGE 2014, International Conference on Heritage and Sustainable Development. Green Lines Institute for Sustainable Development, pp. 1457-1467.

Poulot, D. 1998. Patrimoine et modernité. L'Harmattan, Paris, 312 pp.

Quesada, G., Fernández, J.M., Argüello Menéndez, J.J., Belón González, J., Rodríguez, C. 1993. Puentes antiguos de interés histórico de Asturias. Principado de Asturias, Oviedo, 408 pp.

Rodrigo J.M., Díaz, J.M., Fernández, S., Fernández, V., Hernández, E., Quintero, V., González, B., López, E. 2012. Registro de paisajes de interés cultural de Andalucía. Criterios y metodología. Revista PH. Instituto Andaluz del Patrimonio Histórico 81, 64-75.

Rodríguez, C. 2008. Geomorfología de la montaña astur-leonesa entre los puertos de Ventana y de Somiedo, Tesis Doctoral, Universidad de Oviedo.

Rodríguez, C. 2015. El relieve de la montaña central asturiana: la sierra de Sobia y el macizo de Somiedo. Real Instituto de Estudios Asturianos, Oviedo, $180 \mathrm{pp}$.

Rodríguez, C. 2017. Glaciarismo y nivoperiglaciarismo en el puerto de San Isidro (Cordillera Cantábrica). In: J. Ruiz, C. García, M. Oliva, D. Gallinar (Eds.), Ambientes periglaciares: avances en su estudio, valoración patrimonial y riesgos asociados. Universidad de Oviedo, Oviedo, pp. 39-59.

Rodríguez, C., Castañón, J.C. 2016. Modos de representación cartográfica de las unidades de paisaje: revisión y propuestas. Ería. Revista de Geografía 99-100-100bis, 15-40. https://doi. org/10.17811/er.99.2016.15-40

Rodríguez, C., Sevilla, J. 2017. El patrimonio territorial y paisajístico de Leitariegos: de la mirada intelectual a la primera acción oficial contemporánea. Boletín de la Asociación de Geógrafos Españoles 74, 61-92. https://doi.org/10.21138/bage.2445.

Rodríguez, F. 1989. La organización agraria de la Montaña Central asturiana. Principado de Asturias, Oviedo, $636 \mathrm{pp}$.

Rössler, M. 2010. Agropastoralism and sustainable development: the recognition of agropastoralism in the framework of international conventions. In: F. Lerin (Ed.), Pastoralisme méditerranéen: patrimoine culturel et paysager et développement durable. Montpellier: CIHEAM/AVECC/ UNESCO, pp. 9-15.

Ruiz, J. 2002. Recursos didácticos en Geografía física: itinerario pedagógico sobre el paisaje natural del oriente de Asturias. Espacio, tiempo y forma. Serie VI, Geografía 15, 147-166.

Sánchez, C. 1972. Una vía romana en Asturias. La vía de la Mesa y de Lutos en el Reino de Asturias. In: Orígenes de la nación española. Tomo I, Oviedo, pp. 118-127.

Sánchez, J.O. 1988. Estrategias económicas entre los Vaqueiros de Alzada del concejo de Somiedo (Asturias). Boletín del Instituto de Estudios Asturianos 125, 189-213.

Sanz, C., Mata, R. (Dirs.) 2003. Atlas de los paisajes de España. Ministerio de Medio Ambiente, 683 pp.

Serrano, E. (2012). Montañas, paisaje y patrimonio. Nimbus 29-30, 701-718.

Sevilla, J., Rodríguez, C. 2015. La dinámica reciente del paisaje del puerto de Leitariegos (montaña occidental asturleonesa) a través de la fotografía aérea. Ería. Revista de Geografía 98, 241274. https://doi.org/10.17811/er.98.2015.241-274.

UNESCO 2018a. World Heritage Convention. Operational Guidelines. Available at: https://whc. unesco.org/en/guidelines (Last access: 13/10/2018).

UNESCO 2018b. World Heritage Convention. The List. Available at: https://whc.unesco.org/en/ list/ (Last access: 13/10/2018).

Uría, J. 1976. Los vaqueiros de Alzada y otros estudios (de caza y etnografía). Biblioteca Popular Asturiana, Oviedo, 416 pp. 